\begin{abstract}
"This is the peer reviewed version of the following article: [J. Am. Chem. Soc. 2020, 142, 3149-3157] which has been published in final form at [Link to final article using the DOI: https://dx.doi.org/10.1021/jacs.9b12804]. This article may be used for non-commercial purposes in accordance with the American Chemical Society Terms and Conditions for Self-Archiving."
\end{abstract}

\title{
C-H Bond Activation by an Isolated Dinuclear U(III)/U(IV) Nitride
}

\author{
Chad T. Palumbo, ${ }^{\text {a }}$ Rosario Scopelliti, ${ }^{a}$ Ivica Zivkovic ${ }^{b}$ and Marinella Mazzanti*a \\ ansititut des Sciences et Ingénierie Chimiques, Ecole Polytechnique Fédérale de Lausanne (EPFL), 1015 Lausanne, \\ Switzerland \\ b Laboratory for Quantum Magnetism, Institute of Physics, Ecole Polytechnique Fédérale de Lausanne (EPFL), CH- \\ 1015 Lausanne, Switzerland. \\ Email: mmazzanti@epfl.ch \\ *To whom correspondence should be addressed.
}

\begin{abstract}
Synthetic studies of bimetallic uranium nitride complexes with the $\mathrm{N}\left(\mathrm{SiMe}_{3}\right)_{2}$ ligand have generated a new nitride complex of $\mathrm{U}(\mathrm{III})$, which is highly reactive toward $\mathrm{C}-\mathrm{H}$ bonds and $\mathrm{H}_{2}$. Treatment of the previously reported U(IV)/U(IV) nitride complex $\left[\mathrm{Na}(\mathrm{DME})_{3}\right]\left[\left(\left(\mathrm{Me}{ }_{3} \mathrm{Si}\right)_{2} \mathrm{~N}\right)_{2} \mathrm{U}(\mu-\mathrm{N})\left(\mu-\kappa^{2}-C, N-\mathrm{CH}_{2} \mathrm{SiMe}_{2} \mathrm{NSiMe}_{3}\right) \mathrm{U}\left(\mathrm{N}\left(\mathrm{SiMe}_{3}\right)_{2}\right)_{2}\right], \quad \mathbf{1}$, with 2 equivalents of $\mathrm{HNEt}_{3} \mathrm{BPh}_{3}$ yielded the cationic U(IV)/U(IV) nitride complex, [\{((Mes $\left.\left.\left.\mathrm{Si}_{2} \mathrm{~N}\right)_{2} \mathrm{U}(\mathrm{THF})\right\}_{2}(\mu-\mathrm{N})\right]\left[\mathrm{BPh}_{4}\right], 3$, by successive protonolysis of one $\mathrm{N}\left(\mathrm{SiMe}_{3}\right)_{2}$ ligand and the uranium-methylene bond. Reduction of $\mathbf{3}$ with $\mathrm{KC}_{8}$ afforded a rare example of a U(III) nitride, namely, the U(III)/U(IV) complex, $\left[\left\{\left(\left(\mathrm{Me}_{3} \mathrm{Si}\right)_{2} \mathrm{~N}\right)_{2} \mathrm{U}(\mathrm{THF})\right\}_{2}(\mu-\mathrm{N})\right], 4$. Complex 4 is highly reactive and undergoes 1,2addition of the $\mathrm{C}-\mathrm{H}$ bond of the $\mathrm{N}\left(\mathrm{SiMe}_{3}\right)_{2}$ ligand across the uranium-nitride moiety to give the $\mathrm{U}(\mathrm{III}) / \mathrm{U}(\mathrm{IV})$ imide cyclometalate complex, $\left.\left[\left(\left(\mathrm{Me}_{3} \mathrm{Si}\right)_{2} \mathrm{~N}\right)_{2}(\mathrm{THF}) \mathrm{U}(\mu-\mathrm{NH})\left(\mu-\kappa^{2}-C, N-\mathrm{CH}_{2} \mathrm{SiMe}_{2} \mathrm{NSiMe}_{3}\right) \mathrm{U}\left(\mathrm{N}\left(\mathrm{SiMe}_{3}\right)_{2}\right)\right)(\mathrm{THF})\right], \mathbf{5}$. Complex 4 also reacts with toluene at $-80{ }^{\circ} \mathrm{C}$ to yield an inverse sandwich imide complex arising from $\mathrm{C}-\mathrm{H}$ bond activation of toluene, $\left[\left\{\left(\left(\mathrm{Me}_{3} \mathrm{Si}\right)_{2} \mathrm{~N}\right)_{2} \mathrm{U}(\mathrm{THF})_{2}(\mu-\mathrm{N})\right]\left[\left\{\left(\left(\mathrm{Me}_{3} \mathrm{Si}\right)_{2} \mathrm{~N}\right)_{3} \mathrm{U}(\mu-\mathrm{NH}) \mathrm{U}\left(\mathrm{N}\left(\mathrm{SiMe}_{3}\right)_{2}\right\}_{2}\left(\mathrm{C}_{7} \mathrm{H}_{8}\right)\right], 6\right.\right.$. Complex 4 effects the heterolytic cleavage of the $\mathrm{C}-\mathrm{H}$ of phenylacetylene to yield the imide acetylide $\left[\left\{\left(\left(\mathrm{Me}_{3} \mathrm{Si}\right)_{2} \mathrm{~N}\right)_{2} \mathrm{U}(\mathrm{THF})\right\}_{2}(\mu-\mathrm{N})\right]\left[\left(\left(\mathrm{Me}_{3} \mathrm{Si}\right)_{2} \mathrm{~N}\right)_{2} \mathrm{U}\left(\kappa^{1}-\mathrm{CCPh}\right)\left(\mu_{2}-\mathrm{NH}\right)\left(\mu_{2}-\eta^{2}: \eta^{1-}\right.\right.$ $\left.\mathrm{CCPh}) \mathrm{U}\left(\mathrm{N}\left(\mathrm{SiMe}_{3}\right)_{2}\right)_{2}\right]$, 7. Complex 4 also reacts with $\mathrm{H}_{2}$ to produce an imide hydride U(III)/U(IV) complex, $\left[\left\{\left(\left(\mathrm{Me}_{3} \mathrm{Si}\right)_{2} \mathrm{~N}\right)_{2} \mathrm{U}(\mathrm{THF})\right\}_{2}(\mu-\mathrm{NH})(\mu-\mathrm{H})\right], 9$. These data demonstrate that nitride complexes of $\mathrm{U}(\mathrm{III})$ are accessible with amide ligands and show the high reactivity of molecular U(III) nitrides in $\mathrm{C}-\mathrm{H}$ bond activation.
\end{abstract}

\section{Introduction}

$\mathrm{C}-\mathrm{H}$ bond functionalization remains of great interest in modern chemistry. Compared to analogous metal-oxo or metal-imido species, only a few examples of $\mathrm{C}-\mathrm{H}$ bond activation by metal-nitrides have been reported, and in most cases the nitride species have not been isolated. ${ }^{1}$ Actinide nitrides have recently been the subject of an increasing number of reports that have provided fundamental insight into the nature of actinide-ligand multiple bonding ${ }^{2}$ and shown novel reactivity toward small unreactive molecules such as $\mathrm{CO}_{2}, \mathrm{~N}_{2}, \mathrm{H}_{2}$, and $\mathrm{CO},{ }^{3}$ and the ability to promote $\mathrm{C}-\mathrm{H}$ bond activation. ${ }^{1 e, 4}$

In particular, molecular uranium nitride compounds can be viewed as models of inorganic uranium(III) nitride materials (UN) which have proven effective as catalysts in the Haber-Bosch conversion of dinitrogen and hydrogen into ammonia. ${ }^{5}$ However, the majority of terminal and bridging uranium nitrides isolated in recent years contain uranium in high oxidation states ranging from $U(V I)$ to U(IV). ${ }^{2 a}, 3 b, 4 c, 6$ Only one example of a nitride bridged 
diuranium(III) complex was reported so far, ${ }^{7}$ and it was shown to effect the complete cleavage and functionalization of dinitrogen ${ }^{3 \mathrm{~d}}$ confirming the interest of uranium(III) complexes as uranium nitride analogues. Nitride-bridged U(III)U(IV) and U(III)-U(III) complexes have only been reported in the presence of the siloxide ligand $\mathrm{OSi}\left(\mathrm{O}^{t} \mathrm{Bu}\right)_{3}$, despite that several U(IV)-U(IV) bridging nitrides are known with different supporting ligands. 2f, 4c, 6d, 6k Hence, most studies of uranium nitride reactivity are so far limited to U(IV) and U(VI).

Reactivity studies on uranium nitrides include rare examples of dihydrogen cleavage $\mathrm{e}^{3 \mathrm{c}, 6 \mathrm{a}}$ and $\mathrm{C}-\mathrm{H}$ activation reactivity. ${ }^{1 \mathrm{e}, 4 \mathrm{a}, 4 \mathrm{~b}, 6 \mathrm{f}, 8}$ Isolated $^{6 \mathrm{f}}$ or transient ${ }^{1 \mathrm{e}}$ terminal U(VI) nitrides showed high reactivity resulting in $\mathrm{C}-\mathrm{H}$ activation and reductive 1,1-insertion of the nitride into the $\mathrm{C}-\mathrm{H}$ bond to afford U(IV) amide complexes, Scheme 1. More recently, the reductive denitrogenation of An(IV) azides was reported to lead to formation of parent imido An(IV) complexes, Scheme 2. On the basis of computational studies, it was proposed that the reaction proceeds via 1,2-addition reactivity of the ligand $\mathrm{C}-\mathrm{H}$ bond across the $\mathrm{An} \equiv \mathrm{N}$ moiety of transient Th(IV) ${ }^{4 c}$ and U(IV) ${ }^{4 b}$ nitrides, but they were neither isolated nor observed.

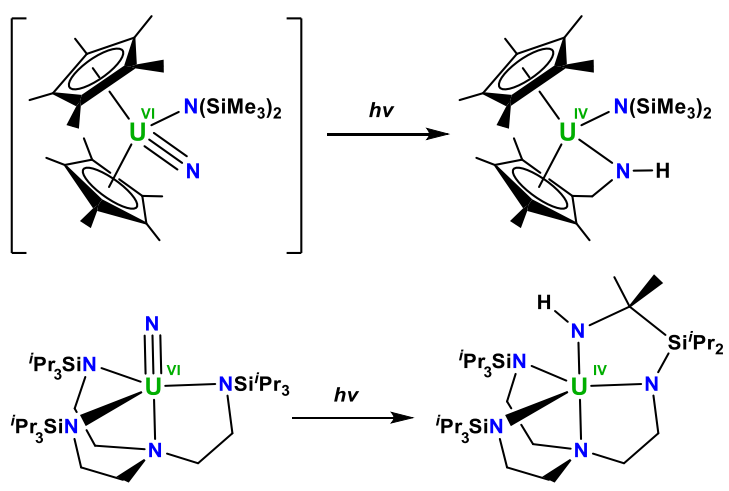

Scheme 1. Previously reported intramolecular insertion reactions of transient ${ }^{1 \mathrm{e}}$ and isolated ${ }^{6 \mathrm{f}}$ uranium(VI) nitride complexes.
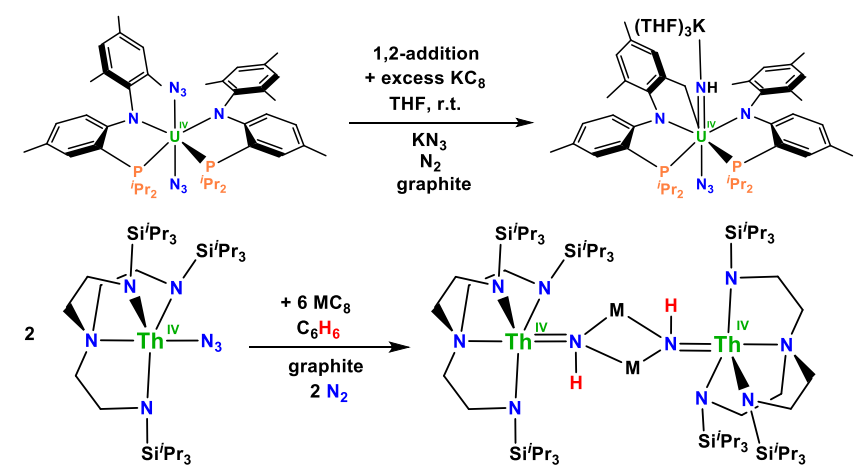

Scheme 2. Previously reported addition reactivity by transient actinide(IV) nitride complexes. $4 c, 4 b$

We recently became interested in the study of uranium nitrides supported by the $\mathrm{N}\left(\mathrm{SiMe}_{3}\right)_{2}$ ligand and showed that the reactivity of the nitride ligand is significantly modified in the diuranium(IV) complexes $\left[\mathrm{NBu}_{4}\right]\left[\left\{\left(\left(\mathrm{Me}{ }_{3} \mathrm{Si}\right)_{2} \mathrm{~N}\right)_{3} \mathrm{U}\right\}_{2}(\mu-\mathrm{N})\right]^{9}$ and

$\left[\mathrm{Na}(\mathrm{dme})_{3}\right]\left[\left(\left(\mathrm{Me} \mathrm{Si}_{3}\right)_{2} \mathrm{~N}\right)_{2} \mathrm{U}(\mu-\mathrm{N})\left(\mu-\kappa^{2}: \mathrm{C}, \mathrm{N}-\right.\right.$

$\left.\left.\mathrm{CH}_{2} \mathrm{SiMe}_{2} \mathrm{NSiMe}_{3}\right) \mathrm{U}\left(\mathrm{N}\left(\mathrm{SiMe}_{3}\right)_{2}\right)_{2}\right], 1^{\text {6c }}$ compared to the siloxide analogue $\left[\left\{\mathrm{U}\left(\mathrm{OSi}\left(\mathrm{O}^{\mathrm{t}} \mathrm{Bu}\right)_{3}\right)_{3}\right\}_{2} \mathrm{Cs}(\mu-\mathrm{N})\right]$. $^{\text {e, } 10}$

Here we show that a U(III)/U(IV) nitride can be prepared using $\mathrm{N}\left(\mathrm{SiMe}_{3}\right)_{2}$ as the supporting ligand and report examples of intramolecular and intermolecular $\mathrm{C}-\mathrm{H}$ activation by the isolated U(III)/U(IV) diuranium nitride. The U(III)/U(IV) diuranium complex $\left[\left\{\left((\mathrm{Me} 3 \mathrm{Si})_{2} \mathrm{~N}\right)_{2} \mathrm{U}(\text { thf })\right\}_{2}(\mu-\mathrm{N})\right], 4$, can be prepared by reduction of the U(IV)/U(IV) analogue at $-80^{\circ} \mathrm{C}$. Upon raising the temperature to $-40{ }^{\circ} \mathrm{C}$, complex 4 undergoes intramolecular $\mathrm{C}-\mathrm{H}$ bond activation by 1,2 -addition of a $\mathrm{C}-\mathrm{H}$ bond from the $\mathrm{N}\left(\mathrm{SiMe}_{3}\right)_{2}$ ligand across the $\mathrm{U}^{\mathrm{III}}=\mathrm{N}=\mathrm{U}^{\mathrm{IV}}$ bond affording the first example of a $\mathrm{NH}$ bridged U(III)/U(IV) diuranium complex. Complex 4 also cleaves $\mathrm{H}_{2}$ and the $\mathrm{C}-\mathrm{H}$ bonds of phenylacetylene and toluene.

\section{Results and discussion}

\section{Preparation of a Cationic U(IV) /U(IV) Nitride.}

With the aim of synthesizing new U(III) nitrides, we first attempted the reduction of the previously reported anionic complexes $\quad\left[\mathrm{NBu}_{4}\right]\left[\left\{\left(\left(\mathrm{Me}_{3} \mathrm{Si}\right)_{2} \mathrm{~N}\right)_{3} \mathrm{U}\right\}_{3}(\mu-\mathrm{N})\right]^{9}$ and $\left[\mathrm{Na}(\text { dme })_{3}\right]\left[\left(\left(\mathrm{Me} \mathrm{Si}_{3}\right)_{2} \mathrm{~N}\right)_{2} \mathrm{U}(\mu-\mathrm{N})\left(\mu-\kappa^{2}: \mathrm{C}, \mathrm{N}-\right.\right.$

$\left.\left.\mathrm{CH}_{2} \mathrm{SiMe}_{2} \mathrm{NSiMe}\right)_{3} \mathrm{U}\left(\mathrm{N}\left(\mathrm{SiMe}_{3}\right)_{2}\right)_{2}\right]$, 1. $^{6 \mathrm{c}}$ In contrast to the reduction of the siloxide U(IV)/U(IV) complex [Cs $\left.\left\{\mathrm{U}\left(\mathrm{OSi}\left(\mathrm{O}^{\mathrm{t} B u}\right)_{3}\right)_{3}\right\}_{2}(\mu-\mathrm{N})\right]$ that led to isolable $\mathrm{U}(\mathrm{III}) / \mathrm{U}(\mathrm{IV})$ and $\mathrm{U}(\mathrm{III}) / \mathrm{U}(\mathrm{III})$ complexes, $\left[\mathrm{Cs}_{2}\left\{\mathrm{U}\left(\mathrm{OSi}\left(\mathrm{O}^{\mathrm{t} B u}\right)_{3}\right)_{3}\right\}_{2}(\mu-\mathrm{N})\right]$ and $\left[\mathrm{Cs}_{3}\left\{\mathrm{U}\left(\mathrm{OSi}\left(\mathrm{O}^{\mathrm{t}} \mathrm{Bu}\right)_{3}\right)_{3}\right\}_{2}(\mu-\mathrm{N})\right]$, such attempts failed to lead to the reduction of the uranium center.

The inability to access the +III oxidation state was attributed to the more electron-rich character of the anionic $\mathrm{N}\left(\mathrm{SiMe}_{3}\right)_{2}$ complexes compared to the siloxide analogues. Therefore, we targeted a cationic $\mathrm{N}\left(\mathrm{SiMe}_{3}\right)_{2}$ complex of uranium(IV) which was expected to be more easily reduced.

Treatment of the previously reported U(IV)/U(IV) nitride complex 1 with $\mathrm{HNEt}_{3} \mathrm{BPh}_{4}$ resulted in protonolysis of a metal-amide bond to yield the neutral THF adduct, $\left[\left(\left(\mathrm{Me}_{3} \mathrm{Si}\right)_{2} \mathrm{~N}\right)_{2} \mathrm{U}(\mu-\mathrm{N})\left(\mu-\kappa^{2}: \mathrm{C}, \mathrm{N}-\right.\right.$

$\left.\mathrm{CH}_{2} \mathrm{SiMe}_{2} \mathrm{NSiMe}_{3}\right) \mathrm{U}\left(\mathrm{N}\left(\mathrm{SiMe}_{3}\right)_{2}\right)$ (THF)], 2, according to Scheme 3. Large single crystals of $\mathbf{2}$ are obtained in $78 \%$ yield upon addition of several drops of THF to a concentrated hexane solution of $\mathbf{2}$ obtained after extraction of the reaction residue. The thermal ellipsoid plot and detailed structural analysis of $\mathbf{2}$ are given in the Supporting Information, Figure S35.

Addition of $\mathrm{HNEt}_{3} \mathrm{BPh}_{4}$ to a solution of 2 in toluene$d_{8}$ caused an immediate change in the ${ }^{1} \mathrm{H}$ NMR spectrum; new resonances at $2.4 \mathrm{ppm}, 1.3 \mathrm{ppm}$, and $-0.74 \mathrm{ppm}$ due to $\mathrm{BPh}_{4}{ }^{-}$were observed along with the $\mathrm{N}\left(\mathrm{SiMe}_{3}\right)_{2}$ resonance at $-3.0 \mathrm{ppm}$ and those of the coordinated THF at $-18.0 \mathrm{ppm}$ and -29.9 ppm, Figure S3. Brown needle crystals of the cationic U(IV)/U(IV) nitride complex, $\left[\left\{\left(\left(\mathrm{Me}_{3} \mathrm{Si}\right)_{2} \mathrm{~N}\right)_{2} \mathrm{U}(\text { thf })\right\}_{2}(\mu-\mathrm{N})\right][\mathrm{BPh} 4], 3$, Scheme 3, Figure 1, were obtained from toluene. The crystals are insoluble in $\mathrm{Et}_{2} \mathrm{O}$, toluene, and hexane but are soluble in THF. 

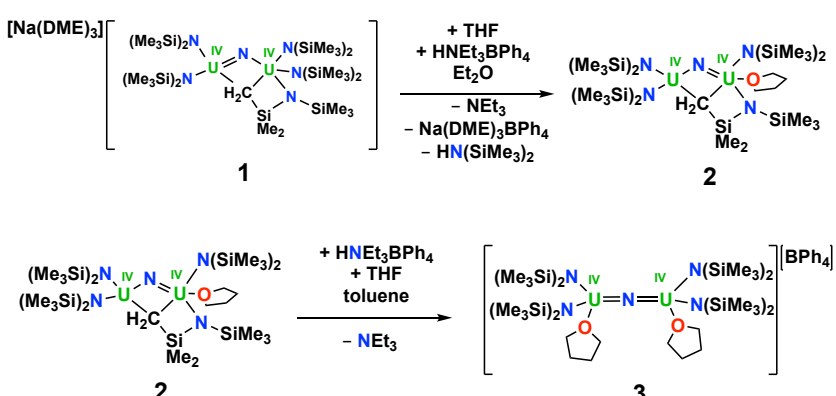

2

3

Scheme 3. Synthesis of complexes $\left[\left(\left(\mathrm{Me}_{3} \mathrm{Si}\right)_{2} \mathrm{~N}\right)_{2} \mathrm{U}(\mu-\mathrm{N})\left(\mu-\kappa^{2}: \mathrm{C}, \mathrm{N}-\mathrm{CH}_{2} \mathrm{SiMe}_{2} \mathrm{NSiMe}\right)_{3}\right) \mathrm{U}(\mathrm{N}(\mathrm{Si}$ $\left.\left.\left.\mathrm{Me}_{3}\right)_{2}\right)(\mathrm{THF})\right], \quad 2$, and $\left[\left\{\left(\left(\mathrm{Me}_{3} \mathrm{Si}\right)_{2} \mathrm{~N}\right)_{2} \mathrm{U}(\mathrm{THF})\right\}_{2}(\mu-\right.$ $\mathrm{N})]\left[\mathrm{BPh}_{4}\right], 3$.

Complex 3 crystallizes in the space group $P \overline{1}$ with one molecule per asymmetric unit. Its solid state structure can be described as an ion pair consisting of an outer sphere $\mathrm{BPh}_{4}{ }^{-}$anion and a U(IV)/U(IV) nitride cation. The cation is comprised of two $\left[\left(\left(\mathrm{Me}_{3} \mathrm{Si}_{2}\right)_{2} \mathrm{~N}\right)_{2} \mathrm{U}(\mathrm{THF})\right]^{2+}$ units bridged by a nitride ligand. $\mathrm{The} \mathrm{SiMe}_{3}$ groups are staggered with respect to those on the adjacent uranium, and the THF ligands are nearly eclipsed. The coordination around the U(IV) ions resembles that of the previously reported ${ }^{9}$ $\left[\mathrm{NBu}_{4}\right]\left[\left\{\left(\left(\mathrm{Me}_{3} \mathrm{Si}\right)_{2} \mathrm{~N}\right)_{3} \mathrm{U}\right\}_{2}(\mu-\mathrm{N})\right]$, except that two $\mathrm{N}\left(\mathrm{SiMe}_{3}\right)_{2}$ ligand have been replaced by neutral THF molecules. The positive charge of $\left[\left\{\left(\left(\mathrm{Me}_{3} \mathrm{Si}\right)_{2} \mathrm{~N}\right)_{2} \mathrm{U}(\mathrm{THF})\right\}_{2}(\mu-\mathrm{N})\right]^{+}$evidently leads to slightly shorter $\mathrm{U}-\mathrm{N}_{\text {nitride }}$ bond distances $(2.055(3)$ $\AA$ and 2.064(3) $\AA$ ) compared to $\left[\mathrm{NBu}_{4}\right]\left[\left\{\left(\left(\mathrm{Me}_{3} \mathrm{Si}\right)_{2} \mathrm{~N}\right)_{3} \mathrm{U}\right\}_{2}(\mu\right.$ $\mathrm{N})](2.075(2)-2.083(5) \AA)$. The U- $\left(\mathrm{N}_{\text {amide }}\right)_{\text {avg }}=2.282(4) \AA$ in 3 is also shorter than that of $\left[\mathrm{NBu}_{4}\right]\left[\left\{\left(\left(\mathrm{Me}_{3} \mathrm{Si}_{2} \mathrm{~N}\right)_{3} \mathrm{U}\right\}_{2}(\mu-\mathrm{N})\right]\right.$, 2.35(1) $\AA$. The $\mathrm{U}-\mathrm{N}-\mathrm{U}$ angle is ca. $169^{\circ}$ in $\mathbf{3}$ whereas it is linear in $\left[\mathrm{NBu}_{4}\right]\left[\left\{\left(\left(\mathrm{Me}_{3} \mathrm{Si}\right)_{2} \mathrm{~N}\right)_{3} \mathrm{U}\right\}_{2}(\mu-\mathrm{N})\right]$.

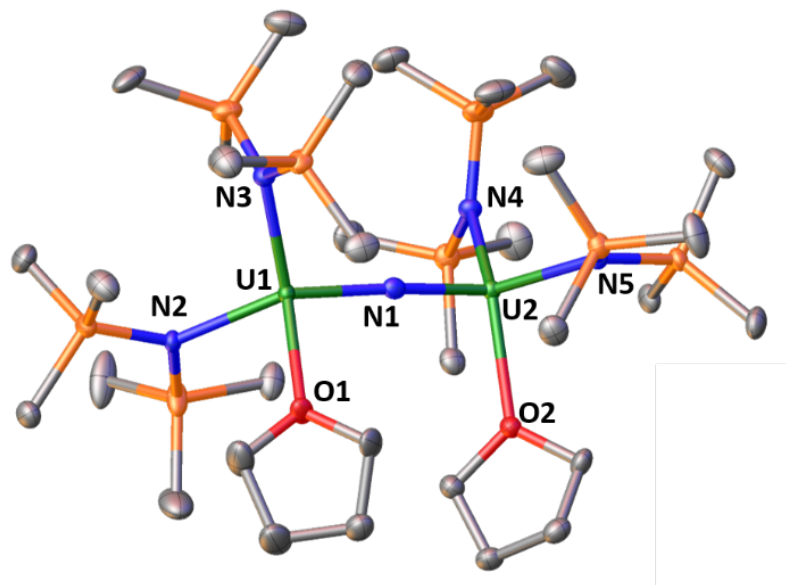

Figure 1. Molecular structure of the cation of $\left[\left\{\left(\left(\mathrm{Me}_{3} \mathrm{Si}\right)_{2} \mathrm{~N}\right)_{2} \mathrm{U}(\mathrm{THF})\right\}_{2}(\mu-\mathrm{N})\right]\left[\mathrm{BPh}{ }_{4}\right], 3$, with thermal ellipsoids drawn at the $50 \%$ probability level. Hydrogen atoms and the $\mathrm{BPh}_{4}{ }^{-}$anion have been omitted for clarity.

\section{Synthesis of a U(III)-U(IV) nitride.}

We found that in contrast to the previously reported anionic nitride complexes supported by $\mathrm{N}\left(\mathrm{SiMe}_{3}\right)_{2}$ ligands, ${ }^{6 c,}, 9 \mathrm{com}-$ plex 3 can be reduced to afford a new example of U(III)$\mathrm{U}(\mathrm{IV})$ nitride. The addition of 1 equiv of $\mathrm{KC}_{8}$ to 3 at room temperature resulted in immediate reaction and yielded a ${ }^{1} \mathrm{H}$ NMR spectrum with several resonances. However, when the reduction was performed at $-80{ }^{\circ} \mathrm{C}$, the low temperature ${ }^{1} \mathrm{H}$ NMR spectrum $\left(-60^{\circ} \mathrm{C}\right)$ showed only a single broad resonance at $-5.1 \mathrm{ppm}$, Figure S6. Crystallization from $\mathrm{Et}_{2} \mathrm{O}$ of the low temperature species at $-80{ }^{\circ} \mathrm{C}$ yielded dark brown crystals of the mixed valent U(III)/U(IV) nitride complex, $\left[\left\{\left(\left(\mathrm{Me}_{3} \mathrm{Si}_{2}\right)_{2} \mathrm{~N}\right)_{2} \mathrm{U}(\mathrm{THF})\right\}_{2}(\mu-\mathrm{N})\right], \mathbf{4}$, Scheme 4, which were characterized by X-ray crystallography, Figure 2.

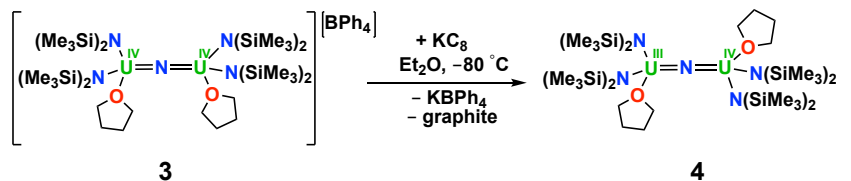

Scheme 4. Reduction of $\left[\left\{\left(\left(\mathrm{Me}_{3} \mathrm{Si}\right)_{2} \mathrm{~N}\right)_{2} \mathrm{U}(\mathrm{thf})\right\}_{2}(\mu-\right.$ $\mathrm{N})]\left[\mathrm{BPh}_{4}\right], 3$, to yield $\left[\left\{\left(\left(\mathrm{Me}_{3} \mathrm{Si}\right)_{2} \mathrm{~N}\right)_{2} \mathrm{U}(\mathrm{THF})\right\}_{2}(\mu-\mathrm{N})\right], 4$.

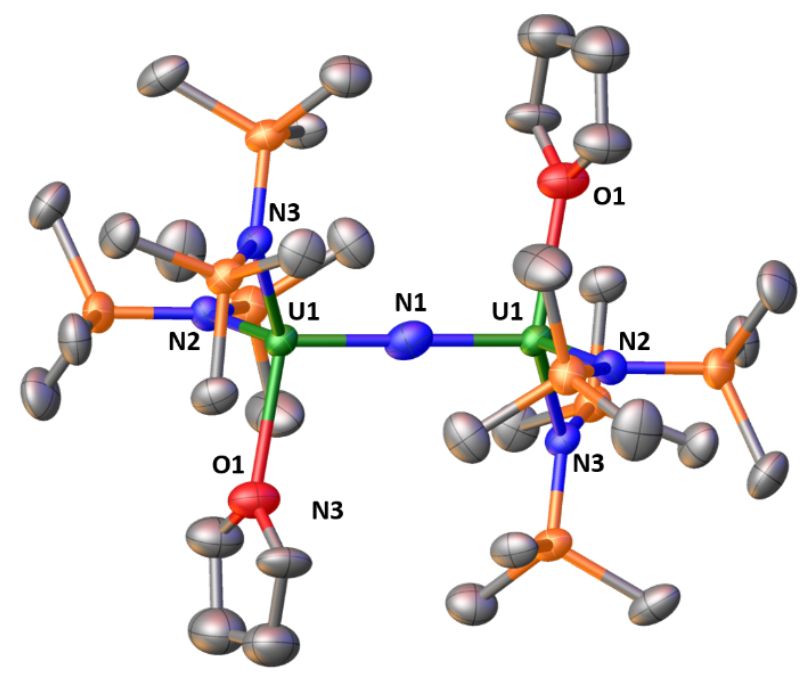

Figure 2. Molecular structure of $\left[\left\{\left(\left(\mathrm{Me}_{3} \mathrm{Si}\right)_{2} \mathrm{~N}\right)_{2} \mathrm{U}(\mathrm{THF})\right\}_{2}(\mu\right.$ $\mathrm{N})$ ], 4, with thermal ellipsoids drawn at the $50 \%$ probability level. Hydrogen atoms and one component of the THF disorder have been omitted for clarity.

Complex 4 crystallizes in the $P \overline{1}$ space group as a neutral $\left[\left\{\left(\left(\mathrm{Me}_{3} \mathrm{Si}\right)_{2} \mathrm{~N}\right)_{2} \mathrm{U}(\mathrm{THF})\right\}_{2}(\mu-\mathrm{N})\right]$ complex composed of two $\left[\left((\mathrm{Me} 3 \mathrm{Si})_{2} \mathrm{~N}\right)_{2} \mathrm{U}(\mathrm{THF})\right]^{n+}(n=1,2)$ moieties that are bridged by a $\mu$-nitride ligand. The overall structure is similar to the cation in 3 but the THF ligands are staggered. The metrical parameters of $\mathbf{4}$ are fully consistent with reduction to U(III). The 2.340(5)-2.351(5) Å range of U-Namide bond distances is significantly longer than the $2.277(3)-2.287(3)$ $\AA$ A range displayed by its parent compound 3. Further, the $\mathrm{U}-\mathrm{O}_{\mathrm{THF}}$ distances are elongated by $0.091 \AA$ in $\mathbf{4}$. However, the uranium-nitride distances do not change significantly $\left(\mathrm{U}-\mathrm{N}_{\text {nitride }}=2.0634(3) \AA\right.$ in 4 and 2.055(3) $\AA$ and 2.064(3) $\AA$ in 3 ), but this is not unexpected. The complexes of $\mathrm{OSi}\left(\mathrm{O}^{t} \mathrm{Bu}\right)_{3}$ do not show significant changes in their $\mathrm{U}-\mathrm{N}_{\text {nitride }}$ distances from $U(I V) / U(I V)$ to $U(I I I) / U(I V)\left(\Delta_{U-N i t r i d e}=0.02\right.$ $\AA)$, nor do the U(V)/U(IV) and U(IV)/U(IV) complexes, $\left[\left\{\left(\left(\mathrm{Me}_{3} \mathrm{Si}\right)_{2} \mathrm{~N}\right)_{3} \mathrm{U}\right\}_{2}(\mu-\mathrm{N})\right]$ and $\left[\mathrm{NBu}_{4}\right]\left[\left\{\left(\left(\mathrm{Me}_{3} \mathrm{Si}\right)_{2} \mathrm{~N}\right)_{3} \mathrm{U}\right\}_{2}(\mu-\mathrm{N})\right]$ $\left(\Delta_{\mathrm{U}-\mathrm{N} \text { itride }}=c a .0 .04 \AA\right),{ }^{9}$ or the $\mathrm{U}(\mathrm{V}) / \mathrm{U}(\mathrm{IV})$ and $\mathrm{U}(\mathrm{IV}) / \mathrm{U}(\mathrm{IV})$ complexes reported by Cummins, $\mathrm{Na}[(\mu-\mathrm{N})(\mathrm{U}(\mathrm{N}[\mathrm{t}-$ $\left.\left.\left.\mathrm{Bu}]_{\mathrm{Ar}}\right)_{3}\right)_{2}\right]$ and $\left[(\mu-\mathrm{N})\left(\mathrm{U}(\mathrm{N}[\mathrm{t}-\mathrm{Bu}] \mathrm{Ar})_{3}\right)_{2}\right],\left(\Delta_{\mathrm{U}-\mathrm{N} \text { itride }}=c a .0 .02\right.$ $\AA$ ). ${ }^{6 d}$ The $\mathrm{U}-\mathrm{N}-\mathrm{U}$ angle is completely linear in $\mathbf{4}$. The metrical parameters of $\mathbf{3}$ and $\mathbf{4}$ are shown in Table 1 below. 
Table 1. Selected bond lengths $(\AA)$ and angles $\left(^{\circ}\right)$ of $\left[\left\{\left(\left(\mathrm{Me}_{3} \mathrm{Si}\right)_{2} \mathrm{~N}\right)_{2} \mathrm{U}(\mathrm{THF})\right\}_{2}(\mu-\mathrm{N})\right]\left[\mathrm{BPh}_{4}\right], \quad 3, \quad$ and $\left[\left\{\left(\left(\mathrm{Me}_{3} \mathrm{Si}\right)_{2} \mathrm{~N}\right)_{2} \mathrm{U}(\mathrm{THF})\right\}_{2}(\mu-\mathrm{N})\right], 4$.

\begin{tabular}{lcc}
\hline & $\mathbf{3}$ & $\mathbf{4}$ \\
\hline $\mathrm{U}-\mathrm{N}_{\text {nitride }}$ & $2.055(3), 2.064(3)$ & $2.0634(3)$ \\
$\mathrm{U}-\mathrm{N}_{\text {amide }}$ & $2.277(3)-2.287(3)$ & $2.340(5)-2.351(5)$ \\
$\mathrm{U}-\left(\mathrm{N}_{\mathrm{a}-}\right.$ & $2.282(4)$ & $2.346(6)$ \\
mide) $)_{\text {avg }}$ & & \\
$\mathrm{U}-\mathrm{O}_{\text {THF }}$ & $2.453(3)$ & $2.544(5)$ \\
$\mathrm{U}-\mathrm{N}-\mathrm{U}$ & $168.97(14)$ & $180.000(15)$ \\
\hline
\end{tabular}

The plots of the magnetic susceptibility $(\chi)$ and of the $\chi \mathrm{T}$ data (Fifures S23-S34) versus T for 3, $\mathbf{4}$ and $\mathbf{5}$ are in agreement with the presence of U(IV)/U(IV) and U(III)/U(IV) complexes respectively ${ }^{11}$ and show no evidence of exchange coupling.

The UV/Visible spectra recorded for complexes $\mathbf{3}$ and $\mathbf{5}$ are compatible with the presence of U(IV)/U(IV) and $\mathrm{U}(\mathrm{III}) / \mathrm{U}(\mathrm{IV})$ complexes respectively.

Complex 4 is only the third example of a crystallographically characterized nitride complex of U(III). The only reported U(III)/U(IV) and U(III)/U(III) bridging nitride complexes are anionic and were isolated using $\mathrm{OSi}\left(\mathrm{O}^{t} \mathrm{Bu}\right)_{3}$ as a supporting ligand. ${ }^{7}$

\section{Reactivity of the U(III)/U(IV) nitride.}

The nitride in the $\mathrm{U}(\mathrm{III}) / \mathrm{U}(\mathrm{IV})$ complex $\mathbf{4}$ is highly reactive and reacts immediately with the $\mathrm{C}-\mathrm{H}$ bonds of $\mathrm{N}\left(\mathrm{SiMe}_{3}\right)_{2}$, toluene, and phenylacetylene, and it readily cleaves the $\mathrm{H}-$ $\mathrm{H}$ bond of dihydrogen. In contrast, the parent complex 3 does not react with any of these substrates.

Complex 4 above $-40{ }^{\circ} \mathrm{C}$ reacts rapidly to afford quantitatively a new species. Single crystals of this product were grown from a concentrated hexane solution at $-40^{\circ} \mathrm{C}$, and X-ray crystallography allowed the identification of a metalate product arising from the 1,2-addition of a $\mathrm{C}-\mathrm{H}$ bond of $\mathrm{N}\left(\mathrm{SiMe}_{3}\right)_{2}$ across the uranium-nitride bond, $\left[\left(\left(\mathrm{Me}_{3} \mathrm{Si}\right)_{2} \mathrm{~N}\right) \mathrm{U}(\mathrm{THF})(\mu-\mathrm{NH})\left(\mathrm{CH}_{2} \mathrm{SiMe}_{2} \mathrm{NSiMe}_{3}\right)-\right.$

$\left.\mathrm{U}\left(\mathrm{N}\left(\mathrm{SiMe}_{3}\right)_{2}\right)_{2}\right], \mathbf{5}$, Scheme 5, Figure 3. Complex 5 displays $\mathrm{SiMe}_{3}$ resonances at $56.4 \mathrm{ppm},-2.93 \mathrm{ppm}$, and $-45.1 \mathrm{ppm}$ in THF- $d_{8}$ at room temperature, Figure S7. The methylene resonances of 4 were identified at $-240 \mathrm{ppm}$ and $-300 \mathrm{ppm}$ and the $\mathrm{NH}$ resonates at $471 \mathrm{ppm}$.

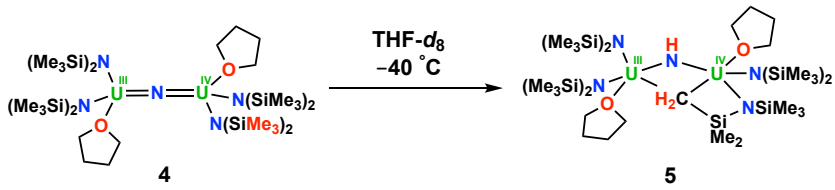

Scheme 5. Intramolecular $\mathrm{C}-\mathrm{H}$ activation by the $\mathrm{U}(\mathrm{III}) / \mathrm{U}(\mathrm{IV})$ nitride 4 , to yield $\left[\left(\left(\mathrm{Me}_{3} \mathrm{Si}\right)_{2} \mathrm{~N}\right) \mathrm{U}(\mathrm{THF})(\mu\right.$ $\left.\mathrm{NH})\left(\mathrm{CH}_{2} \mathrm{SiMe}_{2} \mathrm{NSiMe}_{3}\right) \mathrm{U}\left(\mathrm{N}\left(\mathrm{SiMe}_{3}\right)_{2}\right)_{2}\right], 5$.

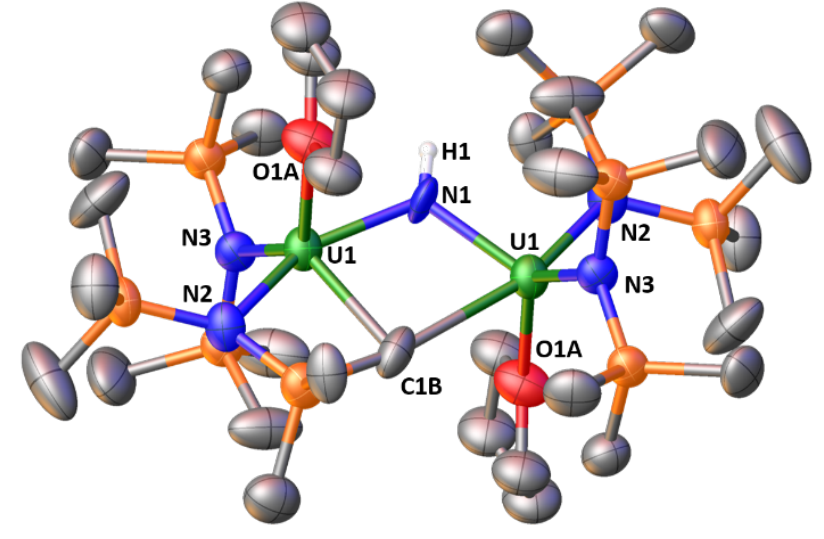

Figure 3. Molecular structure of $\left[\left(\left(\mathrm{Me}_{3} \mathrm{Si}\right)_{2} \mathrm{~N}\right) \mathrm{U}(\mathrm{THF})(\mu-\right.$ $\left.\mathrm{NH})\left(\mathrm{CH}_{2} \mathrm{SiMe}_{2} \mathrm{NSiMe}\right) \mathrm{U}\left(\mathrm{N}\left(\mathrm{SiMe}_{3}\right)_{2}\right)_{2}\right], 5$, with thermal ellipsoids drawn at the $50 \%$ probability level. Hydrogen atoms except H1, disorder in the coordinated THF, and one orientation of 5 have been omitted for clarity. Selected bond lengths $(\AA)$ and angles $\left({ }^{\circ}\right)$ : U1-N1 = 2.151(15) $\AA$, U1$\mathrm{N} 1=2.139(12) \AA ̊ \mathrm{U} 1-\mathrm{N} 2=2.309(7) \AA ̊, \mathrm{U} 1-\mathrm{N} 3=2.329(7) \AA$ $\mathrm{U} 1-\mathrm{C} 1 \mathrm{~B}=2.45(2) \AA ̊ ., \mathrm{U} 1-01 \mathrm{~A}=2.473(11) \AA ̊ ., \mathrm{U} 1-\mathrm{N} 1-\mathrm{U} 1=$ 117.5(7) ${ }^{\circ}, \mathrm{U} 1-\mathrm{C} 1 \mathrm{~B}-\mathrm{U} 1=89.5(9)^{\circ}$.

There are numerous examples ${ }^{6 c, 12}$ of silylmethyl metalation in uranium $/ \mathrm{N}\left(\mathrm{SiMe}_{3}\right)_{2}$ chemistry including the metalation reaction of the nitride complex $\left[\mathrm{NBu}_{4}\right]\left[\left\{\left(\left(\mathrm{Me}_{3} \mathrm{Si}\right)_{2} \mathrm{~N}\right)_{3} \mathrm{U}\right\}_{2}(\mu\right.$ $\mathrm{N})]$ leading to $\left[\mathrm{NBu}_{4}\right]-\mathbf{- 1},{ }^{9}$ but most occur with concomitant loss of one $\mathrm{N}\left(\mathrm{SiMe}_{3}\right)_{2}$ ligand to yield $\mathrm{HN}\left(\mathrm{SiMe}_{3}\right)_{2}$ and the dianionic bidentate ligand $\left[\mathrm{N}\left(\mathrm{SiMe}_{3}\right)\left(\mathrm{SiMe}_{2} \mathrm{CH}_{2}\right)\right]^{2-}$. Reactivity by 1,2-addition across the uranium-nitride bond was previously proposed by Schelter and coworkers for a putative terminal uranium(IV) nitride (Scheme 2). ${ }^{4 \mathrm{~b}}$ The difference in the observed reactivity (insertion vs addition) between the proposed nitrides of U(IV) and U(VI) was inferred from the high energy profile of a reductive insertion process for $\mathrm{U}(\mathrm{IV})$ that would give a $\mathrm{U}(\mathrm{II})$ product. The reaction of $\mathbf{4}$ to generate 5 represents an unambiguous example of this chemistry from a bona fide isolated uranium-nitride and corroborates the argument presented by Schelter and coworkers that 1,2-addition reactivity is favored when lower oxidation states are inaccessible.

The overall structure of $\mathbf{5}$ features a bimetallic U(III)/U(IV) imide cyclometalate complex with two 5-coordinate uranium ions that are bridged by two dianionic ligands, namely an imide $\mu$-NH and a $\mu-\kappa^{2}-N, C$ $\mathrm{CH}_{2} \mathrm{SiMe}_{2} \mathrm{NSiMe}_{3}$ ligand $\mathrm{The} \mu-\kappa^{2}-N, C-\mathrm{CH}_{2} \mathrm{SiMe}_{2} \mathrm{NSiMe}_{3}$ ligand binds one uranium through both the amide nitrogen and the $\mu$-methylene while the other uranium is bound only through the $\mu$-methylene. Charge localization is not evident from the structural data; the $\mathrm{U} 1-\mathrm{N} 1=2.151(15) \AA$ and $2.139(12) \AA ̊$ bond distances are within error. The hydrogen atom $\mathrm{H} 1$ could not be located in the Fourier map but the elongation of the U1-N1 bond distances with respect to those of the nitride 4 (U-N1 = 2.0634(3) $\AA$ ) along with the ${ }^{1} \mathrm{H}$ NMR data (chemical shift $=471 \mathrm{ppm}$ ) are fully consistent with the assignment of $\mathbf{5}$ as an imide complex of uranium.

Complex 4 was also found to activate the toluene $\mathrm{C}-\mathrm{H}$ bond. Notably, addition of toluene $(2 \mathrm{~mL})$ to solid $\mathbf{4}$ at $-80{ }^{\circ} \mathrm{C}$ resulted in an immediate reaction and precipitated dark red crystalline material that gave a complicated ${ }^{1} \mathrm{H}$ 
NMR spectrum after dissolution in THF- $d_{8}$, Figure S8. Recrystallization of the dark crystalline material by slow diffusion of hexane into a dilute toluene solution at $-40{ }^{\circ} \mathrm{C}$ gave crystals characterizable by X-ray crystallography as the tetranuclear arene imide complex, $\left[\left\{\left(\left(\mathrm{Me}_{3} \mathrm{Si}\right)_{2} \mathrm{~N}\right)_{2} \mathrm{U}(\mathrm{THF})\right\}_{2}(\mu-\mathrm{N})\right]-\left[\left\{\left(\left(\mathrm{Me}_{3} \mathrm{Si}\right)_{2} \mathrm{~N}\right)_{3} \mathrm{U}(\mu-\right.\right.$ $\left.\left.\mathrm{NH}) \mathrm{U}\left(\mathrm{N}\left(\mathrm{SiMe}_{3}\right)_{2}\right)\right\}_{2}\left(\mathrm{C}_{7} \mathrm{H}_{8}\right)\right]$, 6, Scheme 6, Figure 4, Table 2.

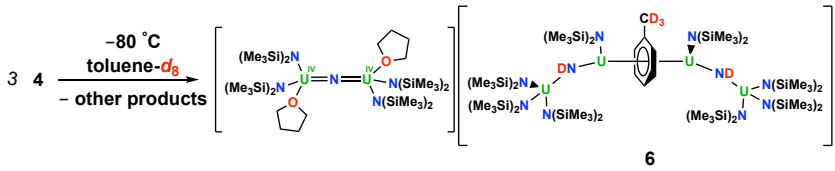

Scheme 6. Reaction of 4, with toluene to yield $\left[\left\{\left(\left(\mathrm{Me}{ }_{3} \mathrm{Si}\right)_{2} \mathrm{~N}\right)_{2} \mathrm{U}(\mathrm{THF})\right\}_{2}(\mu-\mathrm{N})\right]\left[\left\{\left(\left(\mathrm{Me}_{3} \mathrm{Si}\right)_{2} \mathrm{~N}\right)_{3} \mathrm{U}(\mu-\right.\right.$ $\left.\left.\mathrm{NH}) \mathrm{U}\left(\mathrm{N}\left(\mathrm{SiMe}_{3}\right)_{2}\right)\right\}_{2}\left(\mathrm{C}_{7} \mathrm{H}_{8}\right)\right], 6$.

Complex 6 crystallizes in the $P \overline{1}$ space group, and the structure is consistent with an ion pair composed of a $\left[\left\{\left(\left(\mathrm{Me}_{3} \mathrm{Si}\right)_{2} \mathrm{~N}\right)_{2} \mathrm{U}(\mathrm{THF})\right\}_{2}(\mu-\mathrm{N})\right]^{+}$cation similar to that found in 3 and a tetranuclear arene inverse-sandwich imidebridged anion, $\left[\left\{\left(\left(\mathrm{Me}_{3} \mathrm{Si}\right)_{2} \mathrm{~N}\right)_{3} \mathrm{U}(\mu-\mathrm{NH}) \mathrm{U}\left(\mathrm{N}\left(\mathrm{SiMe}_{3}\right)_{2}\right)\right.\right.$ \}$\left._{2}\left(\mathrm{C}_{7} \mathrm{H}_{8}\right)\right]^{-}$. In contrast to the cation in $\mathbf{3}$, the $\left[\left\{\left(\left(\mathrm{Me}_{3} \mathrm{Si}\right)_{2} \mathrm{~N}\right)_{2} \mathrm{U}(\mathrm{THF})\right\}_{2}(\mu-\mathrm{N})\right]^{+}$cation in $\mathbf{6}$ shows staggered THF ligands suggesting their orientation is influenced from packing forces in the crystal. The 2.260(5)-2.272(6) $\AA$ range of $\mathrm{U}-\mathrm{N}_{\mathrm{Nmide}}$ bond distances in the cation is consistent with the U(IV)/U(IV) designation and similar to the 2.277(3)-2.287(3) A range observed in 3. The formal charge on the uranium ions of the anion $\left[\left\{\left(\left(\mathrm{Me}_{3} \mathrm{Si}\right)_{2} \mathrm{~N}\right)_{3} \mathrm{U}(\mathrm{NH}) \mathrm{U}\left(\mathrm{N}\left(\mathrm{SiMe}_{3}\right)_{2}\right)\right\}_{2}\left(\mathrm{C}_{7} \mathrm{H}_{8}\right)\right]^{-}$is ambiguous as is often the case for arene inverse-sandwich complexes of uranium. ${ }^{13}$ Two formulations are plausible for the $\left[\left\{\left(\left(\mathrm{Me}_{3} \mathrm{Si}\right)_{2} \mathrm{~N}\right)_{3} \mathrm{U}(\mathrm{NH}) \mathrm{U}\left(\mathrm{N}\left(\mathrm{SiMe}_{3}\right)_{2}\right)\right\}_{2}\left(\mathrm{C}_{7} \mathrm{H}_{8}\right)\right]^{-}$anion: (1) a combination of three U(III) ions, one U(IV), and a toluenide dianion $\left(\mathrm{C}_{7} \mathrm{H}_{8}\right)^{2-}$, or (2) that with four U(III) ions and a toluenide monoanion $\left(\mathrm{C}_{7} \mathrm{H}_{8}\right)^{1-}$. The $154.2(3)^{\circ}$ and $155.7(4)^{\circ} \mathrm{U}-$ $\mathrm{NH}-\mathrm{U}$ angles are fully consistent with an imide ligand and the hydrogens could be located on the difference Fourier map. The NH resonances were also identified in the ${ }^{1} \mathrm{H}$ NMR spectrum of 6 in THF- $d_{8}$ as two signals at 231 ppm and 216 ppm at $-80^{\circ} \mathrm{C}$ and as one signal at $177 \mathrm{ppm}$ at $-40^{\circ} \mathrm{C}$, Figure S8. Consistent with this assignment, when $\mathbf{4}$ is reacted with toluene- $d_{8}$, an identical complicated ${ }^{1} \mathrm{H}$ NMR spectrum is obtained, but the foresaid resonances are absent, Figure S9. This confirms that the NH group is formed from the cleavage of the toluene $\mathrm{C}-\mathrm{H}$ bond; the fate of the benzyl anion and the source of two electron equivalents remain undetermined.

While the reaction of 4 with toluene to produce 6 was not optimized on a larger scale, the attainment of analytically pure crystals is reproducible. Its crystal structure and ${ }^{1} \mathrm{H}$ NMR spectra clearly show the ability of the highly reactive nitride in $\mathbf{4}$ to promote $\mathrm{C}-\mathrm{H}$ activation of toluene. It should be noted that activation of the toluene $\mathrm{C}-\mathrm{H}$ was previously reported for a transient $U(V)$ terminal nitride ${ }^{6 f}$ and more recently for a putative bridging thorium nitride that could not be isolated.2c However, the previously reported $\mathrm{U}(\mathrm{III}) / \mathrm{U}(\mathrm{IV})$ nitride complex supported by the $\mathrm{OSi}\left(\mathrm{O}^{t} \mathrm{Bu}\right)_{3},{ }^{7}$ was reported to be stable in toluene, suggesting a higher nucleophilic character for the nitride in $\mathbf{4}$.

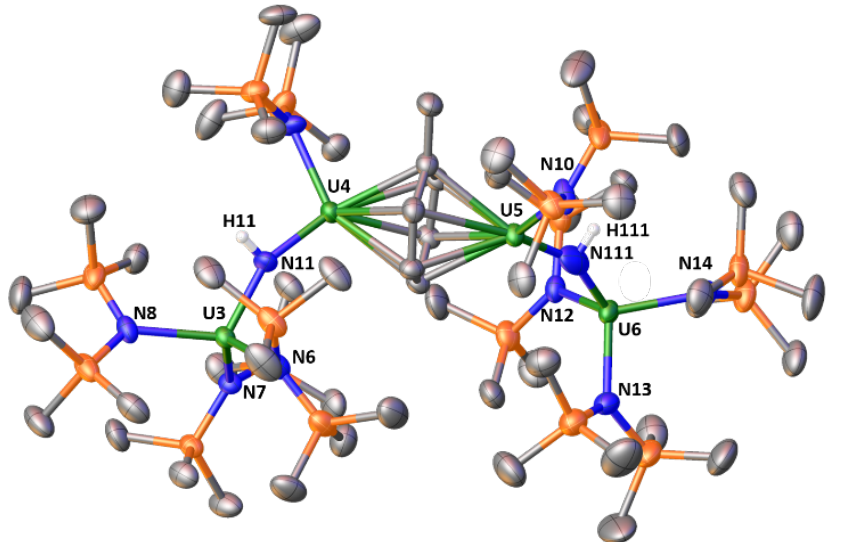

Figure 4. Molecular structure of the anion $\left[\left\{\left(\left(\mathrm{Me}_{3} \mathrm{Si}\right)_{2} \mathrm{~N}\right)_{3} \mathrm{U}(\mu-\mathrm{NH}) \mathrm{U}\left(\mathrm{N}\left(\mathrm{SiMe}_{3}\right)_{2}\right)\right\}_{2}\left(\mathrm{C}_{7} \mathrm{H}_{8}\right)\right]^{-}$in 6, with thermal ellipsoids drawn at the $50 \%$ probability level. Hydrogen atoms except $\mathrm{H} 11$ and $\mathrm{H} 111$ have been omitted for clarity.

Table 2. Selected bond lengths $(\AA)$ and angles $\left(^{\circ}\right)$ of the cation and anion of $\left[\left\{\left(\left(\mathrm{Me}_{3} \mathrm{Si}\right)_{2} \mathrm{~N}\right)_{2} \mathrm{U}(\mathrm{THF})\right\}_{2}(\mathrm{~N})\right]\left[\left\{\left(\left(\mathrm{Me}_{3} \mathrm{Si}\right)_{2} \mathrm{~N}\right)_{3} \mathrm{U}(\mathrm{NH}) \mathrm{U}(\mathrm{N}(\mathrm{Si}\right.\right.$ $\left.\left.\left.\mathrm{Me}_{3}\right)_{2}\right)_{2}\left(\mathrm{C}_{7} \mathrm{H}_{8}\right)\right], 7$.

\begin{tabular}{lcc}
\hline & Cation & Anion \\
\hline $\mathrm{U}-\mathrm{N}$ & $2.040(6)$, & - \\
& $2.044(6)$ & \\
$\mathrm{U}-\mathrm{NH}$ & - & $2.045(5), 2.130(10)$, \\
& & $1.940(10), 2.049(5)$ \\
$\mathrm{U}-\mathrm{N}_{\text {amide }}$ & $2.260(5)-$ & $2.301(5)-2.341(6)$ \\
range & $2.272(6)$ & \\
$\mathrm{U}-\mathrm{N}_{\text {amide }}$ & & \\
mean & & \\
$\mathrm{U}-\mathrm{N}(\mathrm{H})-\mathrm{U}$ & $176.7(4)$ & $154.2(3), 155.7(4)$ \\
angle & & \\
$\mathrm{U}-\mathrm{C}$ range & - & $2.564(7)-2.669(6)$ \\
$\mathrm{U}-\mathrm{C}$ mean & - & $1.425(9)-1.492(9)$ \\
$\mathrm{C}-\mathrm{C}$ range & - & $1.44(1)$ \\
$\mathrm{C}-\mathrm{C}_{\text {avg }}$ & - & \\
\hline
\end{tabular}

In view of its high reactivity with toluene, the reaction of complex 4 with phenylacetylene was also investigated and allowed the discovery that $\mathbf{4}$ heterolytically cleaves the $\mathrm{C}-\mathrm{H}$ bond of phenylacetylene at $-80{ }^{\circ} \mathrm{C}$. The reaction of a THF- $d_{8}$ solution of $\mathbf{4}$ with of phenylacetylene (25 equivalents) at $-80{ }^{\circ} \mathrm{C}$ caused an immediate color change from dark brown to dark red and led to ${ }^{1} \mathrm{H}$ NMR spectra showing a common product, Figure S10. In one attempt, single dark red crystals of $\left[\left\{\left(\left(\mathrm{Me}_{3} \mathrm{Si}\right)_{2} \mathrm{~N}\right)_{2} \mathrm{U}(\mathrm{THF})\right\}_{2}(\mu-\right.$ $\mathrm{N})]\left[\left(\left(\mathrm{Me}_{3} \mathrm{Si}\right)_{2} \mathrm{~N}\right)_{2} \mathrm{U}\left(\eta^{1-\mathrm{CCPh}}\right)\left(\mu_{2}-\mathrm{NH}\right)\left(\mu-\eta^{2}: \eta^{1-}\right.\right.$

$\left.\mathrm{CCPh}) \mathrm{U}\left(\mathrm{N}\left(\mathrm{SiMe}_{3}\right)_{2}\right)_{2}\right]$, 7, Scheme 7, Figure 5, formed from the reaction mixture in $\mathrm{Et}_{2} \mathrm{O}$ at $-80{ }^{\circ} \mathrm{C}$, and the ${ }^{1} \mathrm{H}$ NMR spectra of the crystals showed that $\mathbf{7}$ is the common product, Figure S11. NMR studies of the reaction mixture containing 7 show that even at $-80{ }^{\circ} \mathrm{C}$, the mixture evolves to give a 
complicated spectrum; after $2 \mathrm{~d}$ at $-80{ }^{\circ} \mathrm{C}, 7$ is fully consumed and $\mathrm{HN}\left(\mathrm{SiMe}_{3}\right)_{2}$ is produced, Figure S12. Crystals of a complex arising from the coupling of three equivalents of phenylacetylene and loss of one $\mathrm{HN}\left(\mathrm{SiMe}_{3}\right)_{2}$ ligand, $\left[\left(\left(\mathrm{Me}_{3} \mathrm{Si}\right)_{2} \mathrm{~N}\right) \mathrm{U}(\mathrm{THF})\left(\mu_{2}-\right.\right.$

$\left.\mathrm{NH})(\mathrm{PhCCC}(\mathrm{Ph}) \mathrm{CCC}(\mathrm{Ph})) \mathrm{U}\left(\mathrm{N}\left(\mathrm{SiMe}_{3}\right)_{2}\right)_{2}\right]$, 8, were isolated after crystallization of the reaction residue from hexane at $-40{ }^{\circ} \mathrm{C}$. Structural details of complex 8 can be found in the Supporting Information, Figure S35.

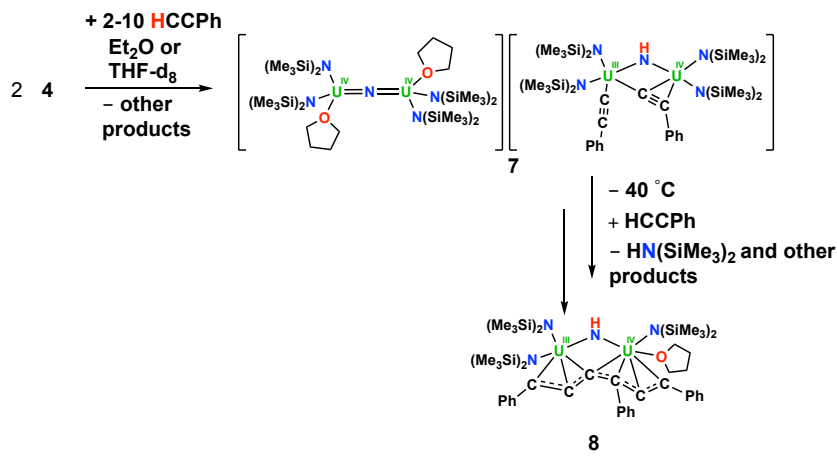

Scheme 7. Reaction of $\left[\left\{\left(\left(\mathrm{Me}_{3} \mathrm{Si}\right)_{2} \mathrm{~N}\right)_{2} \mathrm{U}(\mathrm{THF})\right\}_{2}(\mu-\mathrm{N})\right], 4$, with phenylacetylene to yield $\left[\left\{\left(\left(\mathrm{Me}_{3} \mathrm{Si}\right)_{2} \mathrm{~N}\right)_{2} \mathrm{U}(\mathrm{THF})\right\}\right.$. $\left.{ }_{2}(\mu-\mathrm{N})\right]\left[\left(\left(\mathrm{Me}_{3} \mathrm{Si}\right)_{2} \mathrm{~N}\right)_{2} \mathrm{U}\left(\eta^{1}-\mathrm{CCPh}\right)\left(\mu_{2}-\mathrm{NH}\right)\left(\mu_{2}-\eta^{2}: \eta^{1-}\right.\right.$ $\left.\mathrm{CCPh}) \mathrm{U}\left(\mathrm{N}\left(\mathrm{SiMe}_{3}\right)_{2}\right)_{2}\right], 7$ and $\left[\left(\left(\mathrm{Me}_{3} \mathrm{Si}\right)_{2} \mathrm{~N}\right) \mathrm{U}(\mathrm{THF})\left(\mu_{2}-\right.\right.$ NH)(PhCCC(Ph)CCC(Ph))U(N(SiMe $\left.\left.)_{2}\right)_{2}\right], 8$.

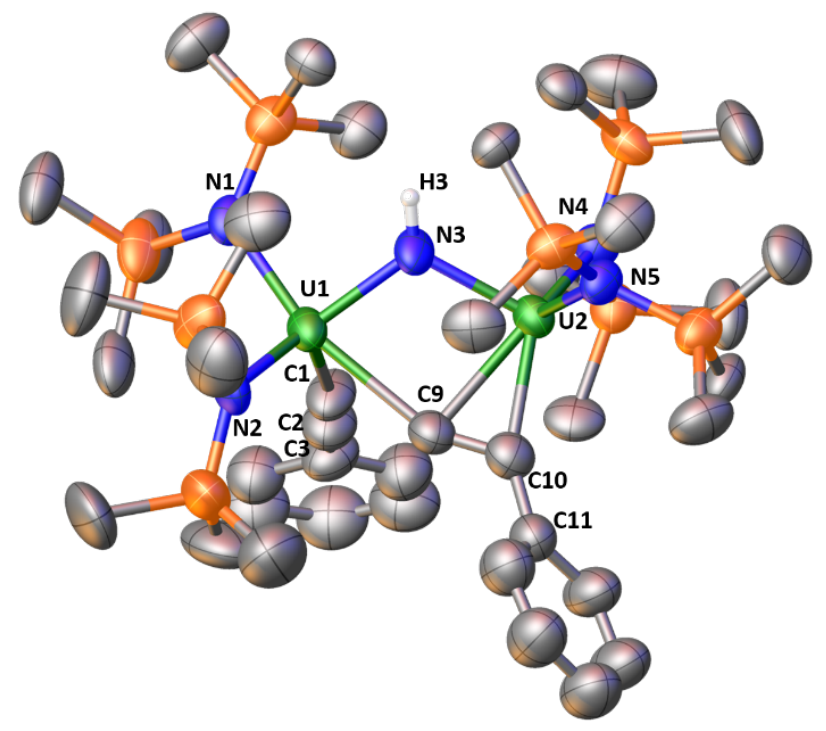

Figure 5. Molecular structure of the anion of $\left[\left(\left(\mathrm{Me}_{3} \mathrm{Si}\right)_{2} \mathrm{~N}\right)_{2} \mathrm{U}\left(\eta^{1-C C P h}\right)\left(\mu_{2}-\mathrm{NH}\right)\left(\mu_{2}-\eta^{2}: \eta^{1-}\right.\right.$

$\left.\mathrm{CCPh}) \mathrm{U}\left(\mathrm{N}\left(\mathrm{SiMe}_{3}\right)_{2}\right)_{2}\right]^{-}$in 7 , with thermal ellipsoids drawn at the $50 \%$ probability level. Hydrogen atoms except $\mathrm{H} 3$ have been omitted for clarity. U1-N3 $=2.146(11) \AA$, U2$\mathrm{N} 3=2.163(13) \AA, \mathrm{U} 1-\mathrm{N} 1=2.307(14) \AA, \mathrm{U} 1-\mathrm{N} 2=$ $2.306(15) \AA$, U2-N4 = 2.310(13) $\AA, \mathrm{U} 2-\mathrm{N} 5=2.279(11) \AA$, $\mathrm{U} 1-\mathrm{C} 1=2.466(16) \AA ̊ \Omega, ~ \mathrm{U} 1-\mathrm{C} 9=2.641(18) \AA, \mathrm{U} 2-\mathrm{C} 9=$ $2.470(16) \AA, U 2-C 10=2.317(17) \AA, C 1-C 2=1.22(2) \AA$, $\mathrm{C} 2-\mathrm{C} 3=1.39(3) \AA ̊ ., \mathrm{C} 9-\mathrm{C} 10=1.33(2) \AA ̊ ., \mathrm{C} 10-\mathrm{C} 11=1.48(3)$ Å, U1-N3-U2 = 114.3(5) ${ }^{\circ}, \mathrm{U} 1-\mathrm{C} 9-\mathrm{U} 2=90.1(5)^{\circ}, \mathrm{C} 1-\mathrm{C} 2-$ C3 $=178(3)^{\circ}$, C9-C10-C11 = 124.2(16) ${ }^{\circ}$.

In the solid state, 7 crystallizes in the $P \overline{1}$ space group with one molecule per asymmetric unit. The overall structure shows an ion pair consisting of the U(IV)/U(IV) cation $\left[\left\{\left(\left(\mathrm{Me} \mathrm{Si}_{2}\right)_{2} \mathrm{~N}\right)_{2} \mathrm{U}(\mathrm{THF})\right\}_{2}(\mu-\mathrm{N})\right]^{+}$as observed in $\mathbf{3}$ and 6 and the bis(acetylide) U(III)/U(IV) imide anion, $\left[\left(\left(\mathrm{Me}_{3} \mathrm{Si}\right)_{2} \mathrm{~N}\right)_{2} \mathrm{U}\left(\kappa^{1-\mathrm{CCPh}}\right)(\mu-\mathrm{NH})\left(\mu-\eta^{2}: \eta^{1-}\right.\right.$

$\left.\mathrm{CCPh}) \mathrm{U}\left(\mathrm{N}\left(\mathrm{SiMe}_{3}\right)_{2}\right)_{2}\right]$. Each uranium ion in the anion of $\mathbf{7}$ is bound by two $\mathrm{N}\left(\mathrm{SiMe}_{3}\right)_{2}$ and one $\mu$-NH ligands and the U1$\mathrm{N} 3=2.146(11) \AA$ and U2-N3 = 2.163 (13) $\AA$ bond distances are consistent with the uranium-imide assignment. The two phenylacetylide ligands show different binding modes. One is bound $\eta^{1}$ to one uranium and the other is bound to both in a $\mu_{2}-\eta^{1}: \eta^{2}$ fashion with one carbon bridging both metals. The $\eta^{1}$ binding has been observed in numerous crystallographically characterized uranium-acetylide complexes, but there are no other examples structurally characterized displaying the $\mu_{2}-\eta^{1}: \eta^{2}$-acetylide binding mode in uranium chemistry. The $2.466(16) \AA$ U1-C1 bond distance is at the longer end of the $2.34-2.47 \AA$ range typical of uranium(IV)-acetylide bond distances. ${ }^{14}$ There is only one other structurally characterized acetylide complex of U(III), ${ }^{15}$ and its 2.589(9) $\AA$ U-Cacetylide distance is significantly longer than the $2.466(16) \AA$ distance of the terminal acetylide in 7.

The formation of complex 7 results from the heterolytic cleavage of the phenylacetylene $\mathrm{C}-\mathrm{H}$ bond by the electrophilic uranium centers and the highly nucleophilic nitride ligand.

Intrigued by the propensity of complex 4 to heterolyze $\mathrm{C}-\mathrm{H}$ bonds, we examined its reactivity with $\mathrm{H}_{2}$. Complex 4 reacts immediately with $\mathrm{H}_{2}$ upon thawing a THF- $d_{8}$ solution of 4 and the ${ }^{1} \mathrm{H}$ NMR spectrum of the reaction mixture showed the presence of two sets of signals that were assigned to complex $\mathbf{5}$ and a new species identified by X-ray crystallography as the imide hydride complex, $\left[\left\{\left(\left(\mathrm{Me}_{3} \mathrm{Si}\right)_{2} \mathrm{~N}\right)_{2} \mathrm{U}(\mathrm{THF})\right\}_{2}(\mu-\mathrm{NH})(\mu-\mathrm{H})\right]$, 9, Scheme 8, Figure 6. Complex 9 crystallizes in the $P \overline{1}$ space group with one molecule per asymmetric unit and can be described as a mixed valent U(III)/U(IV) imide hydride complex. The overall structure consists of a diamond core formed by two $\left[\left(\left(\mathrm{Me}_{3} \mathrm{Si}\right)_{2} \mathrm{~N}\right)_{2} \mathrm{U}(\mathrm{THF})\right]^{n+}(n=1,2)$ units along with $\mu$-NH and $\mu$-H ligands. Each uranium ion is 5-coordinate. The U1-N1 $=2.158(9) \AA$ and the U2-N1 = 2.140(9) $\AA$ bond distances are fully consistent with an imide ligand and delocalized charge on the uranium ions is indicated by the nearly symmetrical $\mathrm{U}-\mathrm{N}_{\text {imide }}$ metrical parameters. Variable temperature ${ }^{1} \mathrm{H}$ NMR studies showed that the reaction of 4 with $\mathrm{H}_{2}$ occurs only above $\mathrm{ca} .-40^{\circ} \mathrm{C}$, a temperature at which the 1,2-addition reaction that gives 5 competes with $\mathrm{H}_{2}$ heterolysis. Thus, at $-40{ }^{\circ} \mathrm{C}$, a mixture of $\mathbf{5} / \mathbf{9}$ is observed, and the ratio of 5/9 was ca. 1:1 in all cases. The ${ }^{1} \mathrm{H}$ NMR spectrum of 9 in THF$d_{8}$ shows one resonance for the $\mathrm{SiMe}_{3}$ groups at $-4.4 \mathrm{ppm}$, Figure S13. The hydride resonance was observed at 597 ppm and the NH resonance at $197 \mathrm{ppm}$. Consistent with this, when 4 is reacted with $D_{2}$, both of these resonances disappear, and the ratio of $\mathbf{5 / 9}$ changes to about 8:1, Figure $\mathrm{S} 14$. The $\mathrm{NH}$ and $\mathrm{CH}_{2}$ resonances of $\mathbf{5}$ do not change in intensity when $1 \mathrm{~atm}$ of $\mathrm{D}_{2}$ is used suggesting that $\mathrm{H} / \mathrm{D}$ exchange does not occur under these conditions. Previously, Andersen and coworkers showed that the uranium(IV) metallate $\left[\mathrm{U}\left(\mathrm{N}\left(\mathrm{SiMe}_{3}\right)_{2}\right)_{2}\left(\mathrm{CH}_{2} \mathrm{SiMe}_{2} \mathrm{NSiMe}_{3}\right)\right]$ can be fully deuterated via $\mathrm{H} / \mathrm{D}$ exchange, but only under high pressure of $\mathrm{D}_{2} .{ }^{12 \mathrm{a}}, 12 \mathrm{c}$ When the headspace of $\mathrm{H}_{2}$ is removed, 9 slowly 
decomposes and a complicated ${ }^{1} \mathrm{H}$ NMR spectrum is obtained. Attempts to independently prepare $\mathbf{9}$ or to separate 9 from $\mathbf{5}$ on a preparatory scale were unsuccessful. Complex $\mathbf{9}$ is a remarkable addition to the rare examples of uranium hydride complexes reported in the literature which are mostly supported by carbocyclic ligands. 16

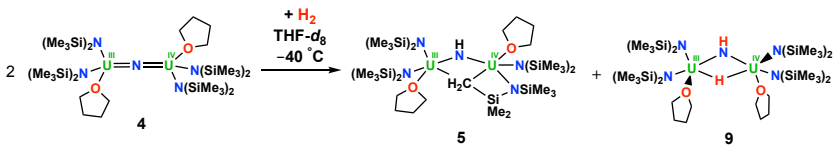

Scheme 8. Reaction of $\left[\left\{\left(\left(\mathrm{Me}_{3} \mathrm{Si}\right)_{2} \mathrm{~N}\right)_{2} \mathrm{U}(\mathrm{THF})\right\}_{2}(\mu-\mathrm{N})\right], 4$, with $\mathrm{H}_{2}$ to yield $\left[\left(\left(\mathrm{Me}_{3} \mathrm{Si}\right)_{2} \mathrm{~N}\right) \mathrm{U}(\mathrm{THF})(\mu\right.$ $\left.\mathrm{NH})\left(\mathrm{CH}_{2} \mathrm{SiMe}_{2} \mathrm{NSiMe}_{3}\right) \mathrm{U}\left(\mathrm{N}\left(\mathrm{SiMe}_{3}\right)_{2}\right)_{2}\right], \quad 5, \quad$ and $\left[\left\{\left(\left(\mathrm{Me}_{3} \mathrm{Si}\right)_{2} \mathrm{~N}\right)_{2} \mathrm{U}(\mathrm{THF})\right\}_{2}(\mu-\mathrm{NH})(\mu-\mathrm{H})\right], 9$.

Heterolytic cleavage of $\mathrm{H}_{2}$ by $\mathrm{U}(\mathrm{IV}) / \mathrm{U}(\mathrm{IV})$ nitride bridged complexes was previously reported by our group, ${ }^{3 c}$, ${ }^{9}$ but this is the first example reported for a U(III) nitride and adds to the handful of reports of heterolytic splitting of $\mathrm{H}_{2}$ by nitride complexes. ${ }^{17}$ Hydrogenolysis by metal nitride intermediates has been identified as a key step in the HaberBosch process. ${ }^{18}$ As such, the cleavage of $\mathrm{H}_{2}$ by a molecular U(III) nitride provides a molecular model for the activity of inorganic UN materials as catalysts ${ }^{5,19}$ in the formation of ammonia from $\mathrm{N}_{2}$ and $\mathrm{H}_{2}$.

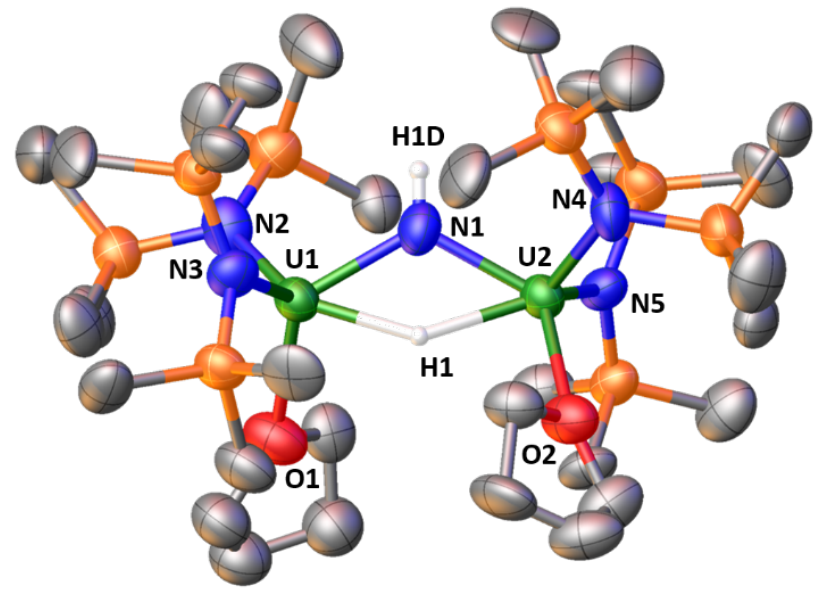

Figure 6. Molecular structure of $\left[\left\{\left(\left(\mathrm{Me}_{3} \mathrm{Si}\right)_{2} \mathrm{~N}\right)_{2} \mathrm{U}(\mathrm{THF})\right\}_{2}(\mu-\mathrm{NH})(\mu-\mathrm{H})\right], 9$, with thermal ellipsoids drawn at the $\mathbf{5 0 \%}$ probability level. Hydrogen atoms except $\mathrm{H} 1$ have been omitted for clarity. U1-N1 $=2.158(9) \AA, \mathrm{U} 2-\mathrm{N} 1=2.140(9) \AA ̊ \mathrm{U} 1-\mathrm{N} 2=2.30(3) \AA$, $\mathrm{U} 1-\mathrm{N} 3=2.37(2) \AA ̊ ., \mathrm{U} 2-\mathrm{N} 4=2.30(2) \AA ̊ ., \mathrm{U} 2-\mathrm{N} 5=2.26(2)$

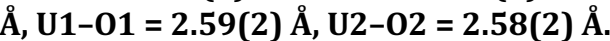

\section{Conclusion}

The $\mathrm{N}\left(\mathrm{SiMe}_{3}\right)_{2}$ ligand system allowed us to isolate a cationic $\mathrm{U}(\mathrm{IV}) / \mathrm{U}(\mathrm{IV})$ nitride that can be further reduced to afford the neutral U(III)/U(IV) nitride (4) that has been fully characterized. Complex 4 is only the third example of a molecular nitride complex of U(III) and the first isolated with a ligand other than $\mathrm{OSi}\left(\mathrm{O}^{t} \mathrm{Bu}\right)_{3}$. The high reactivity of $\mathbf{4}$ was demonstrated by its rapid decomposition at $-40{ }^{\circ} \mathrm{C}$ to afford a U(III)/U(IV) imido metalated product. This result demonstrated $\mathrm{C}-\mathrm{H}$ bond addition across the uranium-nitride bond and the first unambiguous example of 1,2-addition chemistry from an isolated uranium nitride complex which behaves as a strong nucleophile. This result also provides evidence of the key role of the uranium oxidation state in favoring 1,2-addition reactivity over reductive $\mathrm{C}-\mathrm{H}$ insertion. The high reactivity of the uranium-nitride bond toward $\mathrm{C}-$ $\mathrm{H}$ bonds was also demonstrated by the reaction of $\mathbf{4}$ with toluene which resulted in the isolation a tetranuclear arene inverse-sandwich complex which contains imide ligand bridges. The U(III)/U(IV) nitride (4) was also shown to heterolytically cleave the $\mathrm{C}-\mathrm{H}$ bond of phenyacetylene at low temperature to give a U(III)/U(IV) imide acetylide complex. Additionally, 4 effects the heterolytic cleavage of $\mathrm{H}_{2}$ to yield a U(III)/U(IV) imide hydride complex. These results show that U(III) nitrides can be isolated with strong sigma donor amide supporting ligands upon careful choice of reaction condition. The resulting U(III) nitride displays unusually high reactivity toward $\mathrm{C}-\mathrm{H}$ bond activation resulting in the first examples of 1,2 addition of $\mathrm{C}-\mathrm{H}$ bonds across an isolated nitride. Thus, the nature of the supporting ligands can be used to tune the reactivity of U(III) nitrides for the discovery of novel and unusual transformations.

\section{ASSOCIATED CONTENT}

\section{Supporting Information}

X-ray data for $2,3,4,5,6,7,8$, and 9 (CIF) and additional crystallographic details (PDF), experimental procedures, spectroscopic details, and magnetic data of 2, 3, 4 and 5 .

"This material is available free of charge via the Internet at http://pubs.acs.org.".

\section{AUTHOR INFORMATION}

\section{Corresponding Author}

*marinella.mazzanti@epfl.ch.

\section{Author Contributions}

The manuscript was written through contributions of all authors. / All authors have given approval to the final version of the manuscript.

\section{ACKNOWLEDGMENT}

We acknowledge support from the Swiss National Science Foundation grant numbers 178793 and 169699 and the Ecole Polytechnique Fédérale de Lausanne (EPFL). We thank Dr. Euro Solari for carrying out the elemental analyses, Farzaneh Fadaei-Tirani for important contributions to the X-ray single crystal structure analyses.

\section{ABBREVIATIONS}

THF: tetrahydrofuran, DME:1,2-dimethoxyethane .

\section{REFERENCES}

1. (a) Smith, J. M., Reactive Transition Metal Nitride Complexes. Prog. Inorg. Chem. 2014, 58, 417-470; (b) Man, W. L.; Lam, W. W. Y.; Kwong, H. K.; Yiu, S. M.; Lau, T. C., LigandAccelerated Activation of Strong C-H Bonds of Alkanes by a (Salen)ruthenium(VI)-Nitrido Complex. Angew. Chem. Int. Ed. Engl. 2012, 51, 9101-9104; (c) Long, A. K. M.; Timmer, G. H.; Pap, J. S.; Snyder, J. L.; Yu, R. P.; Berry, J. F., Aryl C-H Amination by Diruthenium Nitrides in the Solid State and in Solution at Room Temperature: Experimental and Computational Study of the Reaction 
Mechanism. J. Am. Chem. Soc. 2011, 133, 13138-13150; (d) Atienza, C. C. H.; Bowman, A. C.; Lobkovsky, E.; Chirik, P. J., Photolysis and Thermolysis of Bis(imino)pyridine Cobalt Azides: C-H Activation from Putative Cobalt Nitrido Complexes. J. Am. Chem. Soc. 2010, 132, 16343-16345; (e) Thomson, R. K.; Cantat, T.; Scott, B. L.; Morris, D. E.; Batista, E. R.; Kiplinger, J. L., Uranium azide photolysis results in $\mathrm{C}-\mathrm{H}$ bond activation and provides evidence for a terminal uranium nitride. Nat. Chem. 2010, 2, 723-729.

2 (a) Hayton, T. W., Recent developments in actinide-ligand multiple bonding. Chem. Commun. 2013, 49, 2956-2973; (b) Staun, S. L.; Sergentu, D. C.; Wu, G.; Autschbach, J.; Hayton, T. W., Use of N15 NMR spectroscopy to probe covalency in a thorium nitride. Chem. Sci.2019, 10, 6431-6436; (c) Du, J.Z.; Alvarez-Lamsfus, C.; Wildman, E. P.; Wooles, A. J.; Maron, L.; Liddle, S. T., Thorium-nitrogen multiple bonds provide evidence for pushing-from-below for early actinides. Nat. Commun. 2019, 10, 4203; (d) Anderson, N. H.; Odoh, S. O.; Yao, Y. Y.; Williams, U. J.; Schaefer, B. A.; Kiernicki, J. J.; Lewis, A. J.; Goshert, M. D.; Fanwick, P. E.; Schelter, E. J.; Walensky, J. R.; Gagliardi, L.; Bart, S. C., Harnessing redox activity for the formation of uranium tris(imido) compounds. Nat. Chem . 2014, 6,919926; (e) Panthi, D.; Adeyiga, O.; Dandu, N. K.; Odoh, S. O., Nitrogen Reduction by Multimetallic trans-Uranium Actinide Complexes: A Theoretical Comparison of $\mathrm{Np}$ and $\mathrm{Pu}$ to U. Inorg. Chem. 2019, 58 , 6731-6741; (f) Falcone, M.; Barluzzi, L.; Andrez, J.; Tirani, F. F.; Zivkovic, I.; Fabrizio, A.; Corminboeuf, C.; Severin, K.; Mazzanti, M., The role of bridging ligands in dinitrogen reduction and functionalization by uranium multimetallic complexes. Nat. Chem. 2019, 11, 154-160.

$3 . \quad$ (a) Barluzzi, L.; Falcone, M.; Mazzanti, M., Small molecule activation by multimetallic uranium complexes supported by siloxide ligands. Chem. Commun. 2019, 55, 13031--13047; (b) King, D. M.; Liddle, S. T., Progress in molecular uranium-nitride chemistry. Coord. Chem.Rev. 2014, 266, 2-15; (c) Falcone, M.; Poon, L. N.; Tirani, F. F.; Mazzanti, M., Reversible Dihydrogen Activation and Hydride Transfer by a Uranium Nitride Complex. Angew. Chem. Int. Ed. Engl. 2018, 57, 3697-3700; (d) Falcone, M.; Chatelain, L.; Scopelliti, R.; Zivkovic, I.; Mazzanti, M., Nitrogen reduction and functionalization by a multimetallic uranium nitride complex. Nature 2017, 547, 332-335.

4. (a) Arnold, P. L.; McMullon, M. W.; Rieb, J.; Kuhn, F. E., C-H Bond Activation by f-Block Complexes. Angew. Chem. Int. Ed. Engl. 2015, 54, 82-100; (b) Mullane, K. C.; Ryu, H.; Cheisson, T.; Grant, L. N.; Park, J. Y.; Manor, B. C.; Carroll, P. J.; Baik, M. H.; Mindiola, D. J.; Schelter, E. J., C-H Bond Addition across a Transient Uranium-Nitrido Moiety and Formation of a Parent Uranium Imido Complex. J. Am. Chem. Soc. 2018, 140, 11335-11340; (c) Du, J.; King, D. M.; Chatelain, L.; Tuna, F.; McInnes, E. J. L.; Wooles, A. J.; Maron, L.; Liddle, S. T., Thorium- and Uranium-Azide Reductions: A Transient Dithorium-Nitride Versus Isolable Diuranium-Nitrides. Chem. Sci. 2019, 10, 3738-3745.

5. F. Haber, Ger. Pat. DE229126. 1909

6. (a) Barluzzi, L.; Chatelain, L.; Fadaei-Tirani, F.; Zivkovic, I.; Mazzanti, M., Facile N-functionalization and strong magnetic communication in a diuranium(V) bis-nitride complex. Chem. Sci. 2019, 10, 3543 - 3555; (b) Todorova, T. K.; Gagliardi, L.; Walensky, J. R.; Miller, K. A.; Evans, W. J., DFT and CASPT2 Analysis of Polymetallic Uranium Nitride and Oxide Complexes: How Theory Can Help When X-Ray Analysis Is Inadequate. J. Am. Chem. Soc. 2010, 132, 12397-12403; (c) Fortier, S.; Wu, G.; Hayton, T. W., Synthesis of a Nitrido-Substituted Analogue of the Uranyl Ion, $\mathrm{N}=\mathrm{U}=\mathrm{O}(+) . J$. Am. Chem. Soc. 2010, 132, 6888-6889; (d) Fox, A. R.; Arnold, P. L.; Cummins, C. C., Uranium Nitrogen Multiple Bonding: Isostructural Anionic, Neutral, and Cationic Uranium Nitride Complexes Featuring a Linear U=N=U Core. J. Am. Chem. Soc. 2010, 132, 3250-3251; (e) Camp, C.; Pecaut, J.; Mazzanti, M., Tuning Uranium-Nitrogen Multiple Bond Formation with Ancillary Siloxide Ligands. J. Am. Chem. Soc. 2013, 135, 12101-12111; (f) King, D. M.; Tuna, F.; McInnes, E. J. L.; McMaster, J.; Lewis, W.; Blake, A. J.; Liddle, S. T., Isolation and characterization of a uranium(VI)-nitride triple bond. Nat. Chem. 2013, 15, 482-488; (g) King, D. M.; Tuna, F.; McInnes, E. J. L.; McMaster, J.; Lewis, W.; Blake, A. J.; Liddle, S. T., Synthesis and
Structure of a Terminal Uranium Nitride Complex. Science 2012, 337, 717-720; (h) King, D. M.; McMaster, J.; Tuna, F.; McInnes, E. J. L.; Lewis, W.; Blake, A. J.; Liddle, S. T., Synthesis and Characterization of an f-Block Terminal Parent Imido U=NH Complex: A Masked Uranium(IV) Nitride. J. Am. Chem. Soc. 2014, 136, 5619-5622; (i) Cleaves, P. A.; King, D. M.; Kefalidis, C. E.; Maron, L.; Tuna, F.; McInnes, E. J. L.; McMaster, J.; Lewis, W.; Blake, A. J.; Liddle, S. T., Two-Electron Reductive Carbonylation of Terminal Uranium(V) and Uranium(VI) Nitrides to Cyanate by Carbon Monoxide. Angew. Chem. Int. Ed. Engl. 2014, 53, 10412-10415; (j) King, D. M.; Cleaves, P. A.; Wooles, A. J.; Gardner, B. M.; Chilton, N. F.; Tuna, F.; Lewis, W.; McInnes, E. J. L.; Liddle, S. T., Molecular and electronic structure of terminal and alkali metal-capped uranium(V) nitride complexes. Nat. Commun. 2016, 7, 13773; (k) Tsoureas, N.; Kilpatrick, A. F. R.; Inman, C. J.; Cloke, F. G. N., Steric control of redox events in organo-uranium chemistry: synthesis and characterisation of $\mathrm{U}(\mathrm{V})$ oxo and nitrido complexes. Chem. Sci. 2016, 7, 4624-4632; (1) Evans, W. J.; Kozimor, S. A.; Ziller, J. W., Molecular octa-uranium rings with alternating nitride and azide bridges. Science 2005, 309, 1835-1838; (m) Nocton, G.; Pecaut, J.; Mazzanti, M., A nitrido-centered uranium azido cluster obtained from a uranium azide. Angew. Chem. Int. Ed. Engl. 2008, 47, 3040-3042; (n) Evans, W. J.; Miller, K. A.; Ziller, J. W.; Greaves, J., Analysis of uranium azide and nitride complexes by atmospheric pressure chemical ionization mass spectrometry. Inorg. Chem. 2007, 46, 8008-8018.

7. Chatelain, L.; Scopelliti, R.; Mazzanti, M., Synthesis and Structure of Nitride-Bridged Uranium(III) Complexes. J. Am. Chem. Soc. 2016, 138, 1784-1787.

8. Hayton, T. W., Uranium chemistry. An actinide milestone. Nat. Chem. 2013, 5, 451-452.

9. Palumbo, C. T.; Barluzzi, L.; Scopelliti, R.; Zivkovic, I.; Fabrizio, A.; Corminboeuf, C.; Mazzanti, M., Tuning the structure, reactivity and magnetic communication of nitride-bridged uranium complexes with the ancillary ligands. Chem. Sci. 2019, 10, 8840-8849.

10. (a) Falcone, M.; Kefalidis, C. E.; Scopelliti, R.; Maron, L.; Mazzanti, M., Facile CO Cleavage by a Multimetallic CsU2 Nitride Complex. Angew. Chem. Int. Ed. Engl. 2016, 55, 12290-12294; (b) Falcone, M.; Chatelain, L.; Mazzanti, M., Nucleophilic Reactivity of a Nitride-Bridged Diuranium(IV) Complex: $\mathrm{CO} 2$ and $\mathrm{CS} 2$ Functionalization. Angew. Chem. Int. Ed. Engl. 2016, 55, 4074-4078.

11. (a) Schmidt, A.-C.; Heinemann, F. W.; Lukens, W. W., Jr.; Meyer, K., Molecular and Electronic Structure of Dinuclear Uranium Bis-mu-Oxo Complexes with Diamond Core Structural Motifs. J. Am. Chem. Soc. 2014, 136, 11980-11993; (b) Kindra, D. R.; Evans, W. J., Magnetic Susceptibility of Uranium Complexes. Chem. Rev. 2014, $114,8865-8882$

12. (a) Simpson, S. J.; Turner, H. W.; Andersen, R. A., Hydrogen-Deuterium Exchange

Perdeuteriohydridotris(Hexamethyldisilylamido)-Thorium(Iv) and Uranium(Iv). J. Am. Chem. Soc. 1979, 101, 7728-7729; (b) Gardner, B. M.; McMaster, J.; Lewis, W.; Blake, A. J.; Liddle, S. T., A Crystallizable Dinuclear Tuck-In-Tuck-Over Tuck-Over Dialkyl Tren Uranium Complex and Double Dearylation of BPh4- To Give the $\mathrm{BPh} 2$-Functionalized Metallocycle $\mathrm{U}\left\{\mathrm{N}\left(\mathrm{CH}_{2} \mathrm{CH}_{2} \mathrm{NSiMe}_{3}\right)(2)\left(\mathrm{CH}_{2} \mathrm{CH}_{2} \mathrm{NSiMe}_{2} \mathrm{CHBPh}_{2}\right)\right\}(\mathrm{THF}) . \quad J . \quad A m$. Chem. Soc. 2009, 131, 10388-10389; (c) Simpson, S. J.; Turner, H. W.; Andersen, R. A., Preparation and hydrogen-deuterium exchange of alkyl and hydride bis(trimethylsilyl)amido derivatives of the actinide elements. Inorg. Chem. 1981, 20, 2991-2995; (d) Graves, C. R.; Schelter, E. J.; Cantat, T.; Scott, B. L.; Kiplinger, J. L., A Mild Protocol To Generate Uranium(IV) Mixed-Ligand Metallocene Complexes using Copper(I) Iodide. Organometallics 2008, 27, 5371-5378.

13. (a) Camp, C.; Mougel, V.; Pecaut, J.; Maron, L.; Mazzanti, M., Cation-Mediated Conversion of the State of Charge in Uranium Arene Inverted-Sandwich Complexes. Chem. Eur. J. 2013, 19, 17528 17540; (b) Vlaisayljevich, B.; Diaconescu, P. L.; Lukens, W. L., Jr.; 
Gagliardi, L.; Cummins, C. C., Investigations of the Electronic Structure of Arene-Bridged Diuranium Complexes. Organometallics 2013, 32, 1341-1352; (c) Evans, W. J.; Kozimor, S. A.; Ziller, J. W.; Kaltsoyannis, N., Structure, reactivity, and density functional theory analysis of the six-electron reductant, (C5Me5)(2)U (2)(mueta(6):eta(6)-C6H6), synthesized via a new mode of (C5Me5)(3)M reactivity. J. Am. Chem. Soc. 2004, 126, 14533-14547; (d) Diaconescu, P. L.; Cummins, C. C., mu-eta(6),eta(6)-Arene-Bridged Diuranium Hexakisketimide Complexes Isolable in Two States of Charge. Inorg. Chem. 2012, 51, 2902-2916; (e) Patel, D.; Moro, F.; McMaster, J.; Lewis, W.; Blake, A. J.; Liddle, S. T., A Formal High Oxidation State Inverse-Sandwich Diuranium Complex: A New Route to f-BlockMetal Bonds. Angew. Chem. Int. Ed. Engl. 2011, 50, 10388-10392; (f) Mills, D. P.; Moro, F.; McMaster, J.; van Slageren, J.; Lewis, W.; Blake, A. J.; Liddle, S. T., A delocalized arene-bridged diuranium single-molecule magnet. Nat. Chem. 2011, 3, 454-460; (g) Monreal, M. J.; Khan, S. I.; Kiplinger, J. L.; Diaconescu, P. L., Molecular quadrangle formation from a diuranium mu-eta(6), eta(6)-toluene complex. Chem. Commun. 2011, 47, 9119-9121; (h) Liddle, S. T., Inverted sandwich arene complexes of uranium. Coord. Chem. Rev. 2015, 293, 211-227; (i) Diaconescu, P. L.; Arnold, P. L.; Baker, T. A.; Mindiola, D. J.; Cummins, C. C., Arene-bridged diuranium complexes: Inverted sandwiches supported by delta backbonding. J. Am. Chem. Soc. 2000, 122, 6108-6109.

14. (a) Graves, C. R.; Scott, B. L.; Morris, D. E.; Kiplinger, J. L., Tetravalent and pentavalent uranium acetylide complexes prepared by oxidative functionalization with $\mathrm{CuC} \mathrm{CPh}$. Organometallics $\mathbf{2 0 0 8}$, 27, 3335-3337; (b) Wang, J. Q.; Dash, A. K.; Berthet, J. C.; Ephritikhine, M.; Eisen, M. S., Selective dimerization of terminal alkynes promoted by the cationic actinide compound (Et2N)(3) $\mathrm{U} \mathrm{BPh} 4$ . Formation of the alkyne pi-complex $(\mathrm{Et} 2 \mathrm{~N})(2) \mathrm{U}(\mathrm{C}(\mathrm{CBu})-\mathrm{Bu}-\mathrm{t})$ (eta(2)-HC (CBu)-Bu-t) BP4. Organometallics 1999, 18, 2407-2409.

15. Matson, E. M.; Fanwick, P. E.; Bart, S. C., Formation of Trivalent U-C, U-N, and U-S Bonds and Their Reactivity toward Carbon Dioxide and Acetone. Organometallics 2011, 30, 5753-5762.

16. (a) Ephritikhine, M., Synthesis, structure, and reactions of hydride, borohydride, and aluminohydride compounds of the felements. Chem. Rev. 1997, 97, 2193-2242; (b) Turner, H. W.; Simpson, S. J.; Andersen, R. A., Hydrido Tris(Hexamethyldisilylamido) Thorium(IV) and -Uranium(IV). J. Am. Chem. Soc. 1979, 101, 2782-2782; (c) Manriquez, J. M.; Fagan, P. J.; Marks, T. J., Bis(pentamethylcyclopentadienyl)actinide chemistry properties of stable thorium and uranium dialkyls and hydrides. J. Am. Chem. Soc. 1978, 100, 3939-3941; (d) Fagan, P. J.; Manriquez, J. M.; Maatta, E. A.; Seyam, A. M.; Marks, T. J., Synthesis and Properties of Bis(Pentamethylcyclopentadienyl) Actinide Hydrocarbyls and Hydrides - a New Class of Highly Reactive F-Element Organo-Metallic Compounds. J. Am. Chem. Soc. 1981, 103, 6650-6667; (e) Higgins, J.
A.; Cloke, F. G. N.; Roe, S. M., Synthesis and $\mathrm{CO}_{2}$ Insertion Chemistry of Uranium(IV) Mixed-Sandwich Alkyl and Hydride Complexes. Organometallics 2013, 32, 5244-5252; (f) Evans, W. J.; Montalvo, E.; Kozimor, S. A.; Miller, K. A., Multi-electron reduction from alkyl/hydride ligand combinations in U4+ complexes. J. Am. Chem. Soc. 2008, 130, 12258-12259; (g) Berthet, J. C.; Lemarechal, J. F.; Lance, M.; Nierlich, M.; Vigner, J.; Ephritikhine, M., Synthesis and some reactions of tris(cyclopentadienyl) - uranium(iv) hydrides crystal-structure of $\mathrm{U}\left(\mathrm{C}_{5} \mathrm{H}_{4} \mathrm{BU}(\mathrm{T})\right)_{3} \mathrm{H}$. J. Chem. Soc.-Dalton Trans. 1992, 1573-1577; (h) Evans, W. J.; Miller, K. A.; DiPasquale, A. G.; Rheingold, A. L.; Stewart, T. J.; Bau, R., A crystallizable f-element tuck-in complex: The tuck-in tuck-over uranium metallocene $(\mathrm{C}(5) \mathrm{Me}(5)) \mathrm{U}\{$ mu-eta(5):eta(1):eta(1)-C(5)Me(3)(CH(2))(2)\}(mu$\mathrm{H})(2) \mathrm{U}(\mathrm{C}(5) \mathrm{Me}(5))(2)$. Angew. Chem. Int. Ed. Engl. 2008, 47, 50755078; (i) Pagano, J. K.; Dorhout, J. M.; Czerwinski, K. R.; Morris, D. E.; Scott, B. L.; Waterman, R.; Kiplinger, J. L., Tuning the Oxidation State, Nuclearity, and Chemistry of Uranium Hydrides with Phenylsilane and Temperature: The Case of the Classic Uranium(III) Hydride Complex (C5Me5)(2)U(mu-H) (2). Organometallics 2016, 35, 617-620; (j) La Pierre, H. S.; Scheurer, A.; Heinemann, F. W.; Hieringer, W.; Meyer, K., Synthesis and Characterization of a Uranium(II) Monoarene Complex Supported by delta Backbonding. Angew. Chem. Int. Ed. Engl. 2014, 53, 7158-7162.

17. (a) Brown, S. D.; Mehn, M. P.; Peters, J. C., Heterolytic H2 activation mediated by low-coordinate L3Fe-(mu-N)-FeL3 complexes to generate $\mathrm{Fe}(\mathrm{mu}-\mathrm{NH})(\mathrm{mu}-\mathrm{H}) \mathrm{Fe}$ species. J. Am. Chem. Soc. 2005, 127, 13146-13147; (b) Askevold, B.; Nieto, J. T.; Tussupbayev, S.; Diefenbach, M.; Herdtweck, E.; Holthausen, M. C.; Schneider, S., Ammonia formation by metal-ligand cooperative hydrogenolysis of a nitrido ligand. Nat. Chem. 2011, 3, 532-537; (c) Schoffel, J.; Rogachev, A. Y.; George, S. D.; Burger, P., Isolation and Hydrogenation of a Complex with a Terminal Iridium-Nitrido Bond. Angew. Chem. Int. Ed. Engl. 2009, 48, 4734-4738; (d) Schendzielorz, F. S.; Finger, M.; Volkmann, C.; Wurtele, C.; Schneider, S., A Terminal Osmium(IV) Nitride: Ammonia Formation and Ambiphilic Reactivity. Angew. Chem. Int. Ed. Engl. 2016, 55, 11417-11420.

18. (a) Schlogl, R., Catalytic synthesis of ammonia - A "neverending story"? Angew. Chem. Int. Ed. Engl. 2003, 42, 2004-2008; (b) Jia, H. P.; Quadrelli, E. A., Mechanistic aspects of dinitrogen cleavage and hydrogenation to produce ammonia in catalysis and organometallic chemistry: relevance of metal hydride bonds and dihydrogen. Chem. Soc. Rev. 2014, 43, 547-564.

19. Liu, H.; Ghatak, T.; Eisen, M. S., Organoactinides in catalytic transformations: scope, mechanisms and Quo Vadis. Chem. Commun. 2017, 53, 11278-11297. 


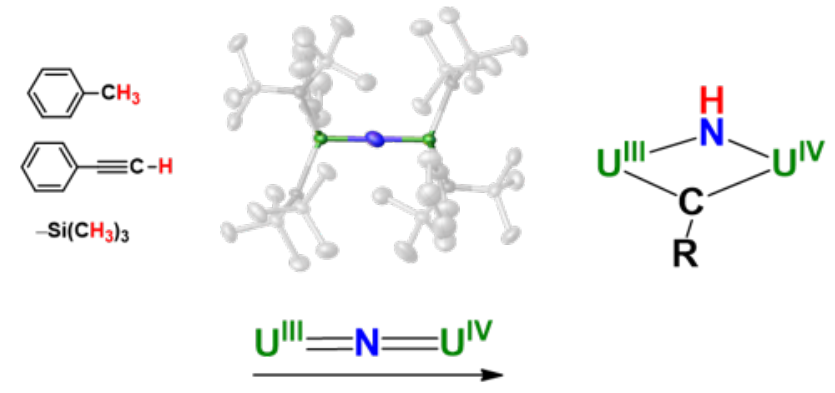

